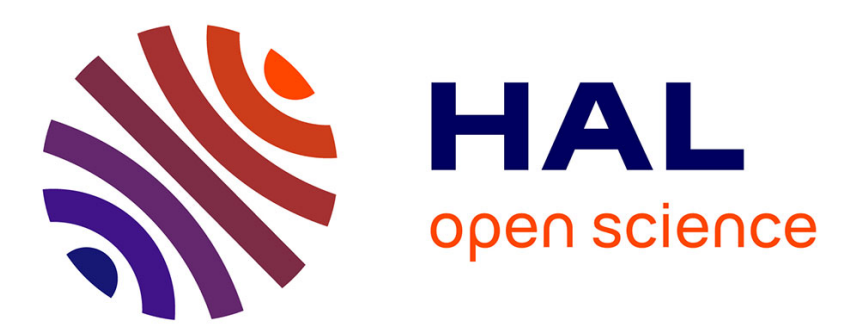

\title{
Investigation of the reaction of ozone with isoprene, methacrolein and methyl vinyl ketone using the HELIOS chamber
}

Yangang Ren, Benoit Grosselin, Véronique Daële, Abdelwahid Mellouki

\section{- To cite this version:}

Yangang Ren, Benoit Grosselin, Véronique Daële, Abdelwahid Mellouki. Investigation of the reaction of ozone with isoprene, methacrolein and methyl vinyl ketone using the HELIOS chamber. Faraday Discussions, 2017, 200, pp.289-311. 10.1039/c7fd00014f . insu-01588945

\section{HAL Id: insu-01588945 \\ https://hal-insu.archives-ouvertes.fr/insu-01588945}

Submitted on 24 May 2018

HAL is a multi-disciplinary open access archive for the deposit and dissemination of scientific research documents, whether they are published or not. The documents may come from teaching and research institutions in France or abroad, or from public or private research centers.
L'archive ouverte pluridisciplinaire HAL, est destinée au dépôt et à la diffusion de documents scientifiques de niveau recherche, publiés ou non, émanant des établissements d'enseignement et de recherche français ou étrangers, des laboratoires publics ou privés. 


\title{
Investigation of the reaction of ozone with isoprene, methacrolein and methyl vinyl
}

\author{
ketone using the HELIOS Chamber
}

\author{
Yangang Ren, Benoit Grosselin, Véronique Daële and Abdelwahid Mellouki \\ Institut de Combustion, Aérothermique, Réactivité et Environnement (ICARE), CNRS (UPR \\ 3021), 1C Avenue de la Recherche Scientifique, 45071 Orléans Cedex 2, France
}

\begin{abstract}
:
The rate constants for the ozonolysis of isoprene (ISO), methacrolein (MACR) and methyl vinyl ketone (MVK) have been measured using the newly built large volume atmospheric simulation chamber at CNRS-Orleans (France), HELIOS (cHambrE de simuLation atmosphérique à Irradiation naturelle d'OrléanS). The $\mathrm{OH}$ radical yields from the ozonolysis of isoprene, MACR and MVK have been also determined as well as the gas phase stable products and their yields. The secondary organic aerosol yield for the ozonolysis of isoprene has been tentatively measured in presence and absence of $\mathrm{OH}$ radicals scavenger. The measurements have been performed under different experimental conditions with and without adding cyclohexane (cHX) as $\mathrm{OH}$ radical scavenger. All experiments have been conducted at 760 torr of purified dry air $(\mathrm{RH} \approx 2.5 \%)$ and ambient temperature $(\mathrm{T}=281-295 \mathrm{~K})$. The data obtained are discussed and compared with those from the literature. The use of the HELIOS facility and its associated analytical equipment enables to derive kinetic parameters as well as mechanistic information in near realistic atmospheric conditions.
\end{abstract}


Keywords: simulation chamber HELIOS, gas-phase, kinetic, ozonolysis, isoprene, methacrolein, methyl vinyl ketone.

Corresponding author: A. Mellouki (mellouki@cnrs-orleans.fr) 


\section{Introduction}

Atmospheric simulation chambers are among the most advanced tools for investigating the atmospheric processes to derive physico-chemical parameters which are required for air quality and climate models. Recently, the ICARE-CNRS at Orléans (France) has set up a new large outdoor simulation chamber, HELIOS (cHambrE de simuLation atmosphérique à Irradiation naturelle d'OrléanS). The new facility has been used to study the ozonolysis of isoprene (ISO), one of the most important volatile organic compounds in the atmosphere, and its major oxidation products, methacrolein (MACR) and methyl vinyl ketone (MVK). Isoprene is the most abundant emitted non-methane hydrocarbon (NMHC) into the atmosphere; it originates mainly from biogenic sources, primarily from terrestrial vegetation. Human activities may affect the lifecycle of these biogenic species and hence change their source capacity. Isoprene is sufficiently active to affect oxidant levels in the lower troposphere and boundary. It is removed from the atmosphere mainly through reaction with $\mathrm{OH}$ radicals during daytime and $\mathrm{NO}_{3}$ radicals during nighttime. However, the reaction with ozone occurs throughout the day and night and hence could have a substantial contribution to the overall removal of isoprene from the atmosphere ${ }^{1}$. The ozonolysis of isoprene has been the subject of large number of studies, in which the reaction rate constant value has been reported at room temperature, using both absolute ${ }^{2-12}$ and relative ${ }^{13-15}$ methods. However, only a limited number of investigations have dealt with the temperature dependence near atmospheric conditions. The few mechanistic studies have indicated that the ozonolysis of isoprene $\left(\mathrm{CH}_{2} \mathrm{C}\left(\mathrm{CH}_{3}\right) \mathrm{CHCH}_{2}\right)$ leads the formation of methacrolein $\left(\mathrm{CH}_{2} \mathrm{C}\left(\mathrm{CH}_{3}\right) \mathrm{CCHO}\right)$, methyl vinyl ketone $\left(\mathrm{CH}_{2} \mathrm{CHC}(\mathrm{O}) \mathrm{CH}_{3}\right)$, and formaldehyde (HCHO) among the carbonyl products in addition to a series of intermediates 
including Criegee intermediates (CIs) which are presently subject to high interest to the atmospheric scientific community ${ }^{10,17-20}$. Indeed, the CIs can react with a number of trace species in the atmosphere to form hydroperoxides, organic acids as well as aerosols ${ }^{3,4}$.

Using the new and well equipped HELIOS facility, we have initiated studies to investigate the chemistry of isoprene and its main oxidation products under conditions close to atmospheric ones. In this first work, we report the rate constants for the reactions of $\mathrm{O}_{3}$ with isoprene, methacrolein and methyl vinyl ketone as well as the yields of the main products formed. The $\mathrm{OH}$ radicals yield from these reactions has been also determined as well as the secondary organic aerosol yield from the ozonolysis of isoprene. The data obtained are discussed and compared to the ones from previous studies. While several studies have been carried out earlier to investigate the reaction of ozone with isoprene, only a limited number have been performed under realistic atmospheric conditions and most of them have been conducted in flow tube system/small chamber using high reactant concentration. (e.g. high initial reactants concentrations) ${ }^{5}$. The reaction of ozone with methacrolein and methyl vinyl ketone have been investigated only in a few studies ${ }^{5}$. The present work provides new insight to the atmospheric importance of these tow reactions. The chemistry of the Criegee intermediates and the subsequent reactions products are not discussed in the present paper, it is subject of an ongoing work in our laboratory.

\section{2-Experimental:}

Experiments were carried out using the newly built large simulation chamber at CNRS-Orleans, HELIOS (cHambrE de simuLation atmosphérique à Irradiation naturelle d'OrléanS): The 
facility consists of $90 \mathrm{~m}^{3}$ hemispherical outdoor simulation chamber $\left(47^{\circ} 50^{\prime} 18.39 \mathrm{~N}\right.$; $\left.1^{\circ} 56^{\prime} 40.03 \mathrm{E}\right)$ made of FEP Teflon film. Two fans installed in the chamber ensure a rapid mixing of reactants (within 90 seconds). Purified air is supplied by a pure air generation system (AADCO Instruments, Inc., 737 series). Pressure $(\mathrm{P})$, relative humidity $(\mathrm{RH})$ and temperature (T) were continuously measured by a three-axis Ultrasonic Anemometer (Delta Ohm, HD 2003) installed in the center of the chamber. In addition, six thermocouples (PT-100), spatially and equally placed in the chamber, were used to measure continuously the temperature distribution, they were found to be within $\pm 1 \mathrm{~K}$. The chamber is protected from "severe" weather conditions such as rain and strong wind by a mobile protective housing which is also used to keep the chamber in full dark conditions in order to conduct ozonolysis experiments such as those reported in the present work. The chamber can be fully exposed to sunlight when needed within $30 \mathrm{~s}$ by automatically moving the protective housing.

Organic compounds were monitored by in situ Fourier transform infrared spectrometry (Bruker Vertex70 spectrometer) coupled to a White-type multipass cell (320.6 m optical path length). Infrared spectra were recorded every 3 minutes by co-adding 250 interferograms with a resolution of $0.4 \mathrm{~cm}^{-1}$. Quantitative analysis of infrared spectra was performed either by subtraction or integration of the peak area using calibrated spectra. The gas phase mixtures were also analyzed using a gas chromatography coupled to a mass spectrometer (GC-MS, PekinElmer Clarus 600 C). Gas samples were collected from the chamber onto Air Toxics trap and analyzed through a thermal desorber (TurboMatrix ${ }^{\mathrm{TM}} 150$ ATD), with split mode, followed by a thermal desorption at $300{ }^{\circ} \mathrm{C}(5 \mathrm{~min})$ delivering the sample to a $60-\mathrm{m}$ column (GasPro diameter $0.320 \mathrm{~mm})$. The temperature of the $\mathrm{GC}$ oven was programmed as follows $25^{\circ} \mathrm{C} \mathrm{min}{ }^{-1}$ 
from $180^{\circ} \mathrm{C}$ to $250^{\circ} \mathrm{C}$ and held for $25 \mathrm{~min}$. Ozone concentrations were measured continuously by a chemiluminescence analyzer (HORIBA, APNA 360). The organics were also monitored by PTR-ToF-MS (Proton Transfer Reaction - Time of Flight-Mass Spectrometer, IONICON 8000). PTR-ToF-MS spectra were analyzed by the PTR-ToF Data Analyzer ${ }^{6}$. HCHO was monitored continuously by an Aerolaser A4021moniror using Hantzsch reaction (Aerolaser GMBH). The detection limits for the main species of interest (isoprene, MACR, MVK, HCHO, and cyclohexanone) were typically $\approx 1-2 \mathrm{ppb}$ by FTIR analysis, $\approx 0.2-0.5 \mathrm{ppb}$ by GCMS, and $\approx 0.1-0.2 \mathrm{ppb}$ by PTR-ToF-MS. The precisions were $\leq 7 \%$. The measurements of HCHO by the A4021moniror had a precision and detection limit of $2 \%$ and $\approx 100 \mathrm{ppt}$, respectively. Ozone concentrations measurement the chemiluminescence analyzer (HORIBA, APOA 370) had a detection limit of $1 \mathrm{ppb}$.

Isoprene (ISO), methacrolein (MACR), methyl vinyl ketone (MVK) and cyclohexane (cHX) were introduced into the chamber by placing known volumes in a bubbler and flushed by a stream of purified air. Their concentrations were derived by considering the volume of the liquid introduced, the pressure and the temperature using the ideal gas law. $\mathrm{O}_{3}$ was generated either through a Trailigaz® ozone generator or by using a Pen-Ray® Mercury Lamp radiation through a flow of $\mathrm{O}_{2}$ prior to be introduced into the chamber. Gaseous reactants (i.e., $\mathrm{SF}_{6}$ ) were injected into the chamber using a calibrated gas cylinder equipped with capacitance manometers. In order to compensate sampling flows and leaks, a slight flow of purified air (15$25 \mathrm{~L} / \mathrm{min}$ ) was added continuously during all experiments maintaining a slight overpressure in 
the chamber, avoiding any contamination from outside air. The dilution rate in the chamber was determined by monitoring the decay of introduced amount of $\mathrm{SF}_{6}$ by FT-IR and was found to be typically $\mathrm{kSF}_{\mathrm{SF}}=(4.6 \pm 0.1) \times 10^{-6} \mathrm{~s}^{-1}$.

Between each experiment, the chamber was cleaned by flushing pure air $(800 \mathrm{~L} / \mathrm{min})$ for at least 12 hours. Background concentrations in the chamber were systematically checked and found to be below the detection limits of the available analytical instruments (e.g., $\left[\mathrm{NO}_{\mathrm{x}}\right]<1.3 \times 10^{10},\left[\mathrm{O}_{3}\right]<1.3 \times 10^{10}$ and $[\mathrm{VOC}]<1.3 \times 10^{8}$ molecule $\left.\mathrm{cm}^{-3}\right)$.

Chemicals. The chemicals used in this work and their stated purities were: Isoprene (Aldrich, 99\%), cHX (Aldrich, 99.5\%), MACR (Aldrich, 95\%), MVK (Aldrich, 98\%), SF6 (Mitry-Mory 99.95\%) and $\mathrm{O}_{2}$ (Alphagaz, 99.9999\%).

\section{3- Results and discussion}

\section{3-1 Kinetic measurements:}

It is well established that the ozonolysis of unsaturated organic compounds constitutes a potential non-photolytic source of $\mathrm{OH}$ radicals under atmospheric conditions ${ }^{7-9}$. Hence, in order to take that into account during our measurements, we have conducted the experiments using three different strategies, (S1) [ISO] in excess over $\left[\mathrm{O}_{3}\right]$ in the absence of cHX; $(\mathrm{S} 2)$ : $\left[\mathrm{O}_{3}\right]$ in excess over [ISO/MACR/MVK] in the presence of cHX (used as $\mathrm{OH}$ scavenger) and (S3): $\left[\mathrm{O}_{3}\right]$ in excess over [ISO/MACR/MVK] in the absence of cHX. Typically, initial $\mathrm{O}_{3}$ and ISO/MACR/MVK concentrations for the (S2) and (S3) strategies were in the range 110-1000 ppb and 9-90 ppb, respectively while initial $\mathrm{O}_{3}$ and isoprene concentrations for (S1) were 13- 
$35 \mathrm{ppb}$ and 100-350 ppb, respectively. When added, cHX concentrations were in the range 1.5$17 \mathrm{ppm}$. Under (S2) and (S3) conditions, ISO/MACR/MVK were introduced into the chamber firstly to derive their losses in the absence of ozone which represent basically the wall loss and dilution. Under ( $\mathrm{S} 1$ ) conditions, $\mathrm{O}_{3}$ was introduced first into the chamber and its loss measured in the absence of organic reactants. Rate constants for the gas-phase reaction of $\mathrm{O}_{3}$ with Organic (ISO/MACR/MVK) were determined by monitoring the enhanced decay rates of the $\mathrm{O}_{3}$ or ORG (organic reactant) depending on the initial concentrations conditions. When the organic reactant is in excess, the decay of the ozone concentration can be expressed as $\left[\mathrm{O}_{3}\right]_{\mathrm{t}}=\left[\mathrm{O}_{3}\right]_{0} \times$ $\exp \left(-k^{\prime} \mathrm{t}\right)$ where $k^{\prime}=k \times[\mathrm{ORG}]_{0}+k^{\prime} 0$, where $k\left(\right.$ in $\mathrm{cm}^{3}$ molecule $\left.\mathrm{e}^{-1} \mathrm{~s}^{-1}\right)$ is the rate coefficient of the ozone reaction with organic, $k^{\prime} 0\left(\right.$ in s $\left.^{-1}\right)$ is the pseudo-first order decay rate of ozone in the absence of the organic reactant and $[\mathrm{ORG}]_{0}$ is the initial concentration of organic. Similarly, when $\mathrm{O}_{3}$ was in excess, the decay of the organic is expressed as $[\mathrm{ORG}]_{t}=[\mathrm{ORG}]_{0} \times \exp \left(-k^{\prime} t\right)$ where $k^{\prime}=k \times\left[\mathrm{O}_{3}\right]_{0}+k_{0}^{\prime}$, where $k^{\prime}{ }_{0}$ is the pseudo-first order decay rate of organic in the absence of $\mathrm{O}_{3}$ and $\left[\mathrm{O}_{3}\right]_{0}$ is the initial concentration of ozone. In our experimental conditions, $k^{\prime}{ }_{0}$ ISO $=(4.9 \pm 0.7) \times 10^{-6}, k^{\prime}{ }_{0 \_\mathrm{MACR}}=(6.0 \pm 1.0) \times 10^{-6}, k^{\prime}{ }_{0 \_\mathrm{MVK}}=(5.7 \pm 1.0) \times 10^{-6}$ and $k^{\prime}{ }_{0 \_} \mathrm{O} 3=$ $(5.0 \pm 0.4) \times 10^{-6} \mathrm{~s}^{-1}$. In excess of $\mathrm{O}_{3}$ when $\mathrm{cHX}$ was not added to scavenge $\mathrm{OH}$ radicals, the loss of the organic due to the reaction with $\mathrm{OH}$ radicals was taken into account to correct the measured kO3 + ORG.

Figures 1(a-d) displays examples of the pseudo-first order rate constants versus the initial concentrations of the species in excess $\left(\mathrm{O}_{3}\right.$ or organic) obtained. The slopes of these plots were used to derive the reactions rate constants. The initial experimental conditions together with the measured rate constants for the reaction of $\mathrm{O}_{3}$ with three organics 
(ISO/MACR/MVK) are listed in Tables 1-3. The runs were performed under ambient temperatures, 280 to $295 \mathrm{~K}$, which were the outdoor temperature during the experiments period. period. Consequently, the results have been assembled by averaging the values from different runs at the same temperature $( \pm 3 \mathrm{~K})$.

In the experiments where isoprene concentrations were in excess over that of $\mathrm{O}_{3}$, a rate constant value of ko3+isoprene $=(8.6 \pm 0.5) \times 10^{-18} \mathrm{~cm}^{3}$ molecule ${ }^{-1} \mathrm{~s}^{-1}$ at $285 \pm 1 \mathrm{~K}$ was obtained. Under conditions where $\mathrm{O}_{3}$ was in excess over the organic in the presence of cyclohexane as $\mathrm{OH}$ scavenger, several runs were performed at $\mathrm{T}=294 \pm 2$ and $285 \pm 2 \mathrm{~K}$ and a single run at $278 \pm 1 \mathrm{~K}$ for the reaction of $\mathrm{O}_{3}$ with isoprene. The obtained values are: $\mathrm{k}_{03+\text { isoprene }}=(11.3 \pm 1.7)$ and $(9.3$ $\pm 0.7) \times 10^{-18} \mathrm{~cm}^{3}$ molecule $\mathrm{s}^{-1}$ at $294 \pm 2$ and $285 \pm 2 \mathrm{~K}$, respectively, in excellent agreement with the IUPAC panel recommendations using the Arrhenius expression $\mathrm{k}=1.03 \times 10^{-14} \exp (-$ $1995 / \mathrm{T}$ ) in the range $240-360 \mathrm{~K}, \mathrm{ko3}+$ isoprene $=11.9$ and $9.4 \times 10^{-18} \mathrm{~cm}^{3}$ molecule $\mathrm{s}^{-1}$. The rate constant value obtained in the single run at $278 \pm 1 \mathrm{~K},(6.7 \pm 0.9) \times 10^{-18} \mathrm{~cm}^{3}$ molecule $\mathrm{s}^{-1}$, is $\approx 15 \%$ lower than the IUPAC recommendation $7.9 \times 10^{-18} \mathrm{~cm}^{3}$ molecule $\mathrm{s}^{-1}$. In the absence of scavenger, the reaction rate constants values obtained at $284 \pm 1,281 \pm 1$, and $288 \pm 1 \mathrm{~K}$ (a single run $)$, respectively, ko3+isoprene $=(10.8 \pm 1.1),(9.7 \pm 0.7)$, and $(11.9 \pm 1.8) \times 10^{-18} \mathrm{~cm}^{3}$ molecule ${ }^{-1} \mathrm{~s}^{-1}$, have been found to be systematically $\approx 15 \%$ higher than those from the IUPAC recommendations $9.16 \times 10^{-18}, 8.5 \times 10^{-18}$, and $10.9 \times 10^{-18} \mathrm{~cm}^{3}$ molecule $\mathrm{e}^{-1} \mathrm{~s}^{-1}$. The reason for the observed differences is attributed to the contribution of the $\mathrm{OH}$ reaction to the consumption of isoprene when $\mathrm{O}_{3}$ was in excess.

Regarding the $\mathrm{O}_{3}$ reactions with MACR and MVK, experiments were conducted only in excess of $\mathrm{O}_{3}$ in the presence and absence of $\mathrm{OH}$ scavenger. In the presence of scavenger, the rate 
constant values obtained at $\mathrm{T}=285 \pm 1 \mathrm{~K}$ for the reaction of $\mathrm{O}_{3}$ with MACR is kO3+MACR $=(7.1$ $\pm 0.6) \times 10^{-19} \mathrm{~cm}^{3}$ molecule ${ }^{-1} \mathrm{~s}^{-1}$ which is slightly lower that the IUPAC recommended value $\left(\mathrm{k}=8.8 \times 10^{-19}\right)$ using the expression $\mathrm{k}=1.4 \times 10^{-15} \exp (-2100 / \mathrm{T}) \mathrm{cm}^{3}$ molecule $\mathrm{e}^{-1} \mathrm{~s}^{-1}$ over the temperature range $240-330 \mathrm{~K}$. The single run carried out at $\mathrm{T}=287 \pm 1 \mathrm{~K}$ leads to slightly lower value, $\mathrm{k}=7.9 \times 10^{-19}$, compared to the recommendation, $9.3 \times 10^{-19}$. The runs performed in absence of scavenger led to higher values: $\mathrm{k}_{282}=(12 \pm 1) \times 10^{-19}$ and $\mathrm{k}_{289}=(15 \pm 2) \times 10^{-19}$ compared to those in the presence of scavenger and also to IUPAC recommendations which are $\mathrm{k}_{282}=8.2 \times 10^{-19}$ and $\mathrm{k}_{289}=8.8 \times 10^{-19} \mathrm{~cm}^{3}$ molecule $\mathrm{e}^{-1} \mathrm{~s}^{-1}$.

The $\mathrm{O}_{3}+\mathrm{MVK}$ rate constant measured at $\mathrm{T}=289 \pm 3 \mathrm{~K}$ in the presence of scavenger was found to be ko3+MVK $=(4.5 \pm 0.1) \times 10^{-18} \mathrm{~cm}^{3}$ molecule $\mathrm{s}^{-1}$ in excellent agreement with the recommended value, $\mathrm{kO}_{\mathrm{O}+\mathrm{MVK}}=4.4 \times 10^{-18}$, using the Arrhenius expression $\mathrm{k}=8.5 \times 10^{-16} \exp (-$ $1520 / \mathrm{T}) \mathrm{cm}^{3}$ molecule $\mathrm{s}^{-1}$ over the temperature range $240-330 \mathrm{~K}$. The experiment performed in absence of the scavenger at $287 \pm 2 \mathrm{~K}$ led to $\mathrm{k}=(5.1 \pm 0.1) \times 10^{-18}$ which is $\approx 20 \%$ higher than the IUPAC preferred one, $\mathrm{k}=4.3 \times 10^{-18} \mathrm{~cm}^{3}$ molecule $\mathrm{s}^{-1}$.

\section{3-2 Products measurements}

\section{3-2-1 OH formation yields}

Cyclohexane was used to scavenge $\mathrm{OH}$ radicals formed during the ozonolysis of ISO, MARC and MVK. The yield of cyclohexanone produced from the reaction of $\mathrm{OH}$ with cyclohexane enabled to derive the $\mathrm{OH}$ yields during the ozonolysis of the investigated organics. Cyclohexanone was monitored by GC-MS (m/z=98) and PTR-ToF-MS $(\mathrm{m} / \mathrm{z}=81.0463$ and 99.0465$)$. The $\mathrm{OH}$ yields were obtained from the equation: 


$$
\mathrm{Y}_{\mathrm{OH}}=\frac{[\text { cyclohexanone }] / \Delta[\text { organic }]}{[\text { cyclohexanone }] / \Delta[\mathrm{cHX}]}=\frac{[\text { cyclohexanone }] / \Delta[\text { organic }]}{0.5}
$$

in which cyclohexanone formation yield of $(50 \pm 7) \%$ from $\mathrm{OH}+$ cyclohexane reported by Atkinson et al. ${ }^{10}$ was used.

Figure 2 shows the formation of cyclohexanone versus the consumed organics during the course of the experiments and Table 4 summarizes the experimental conditions and the obtained yield values. The results obtained are $\mathrm{Y}_{\mathrm{OH}}=24.0 \pm 2.0 ; 14.3 \pm 3.5$ and $13.4 \pm 4.1$ for the reactions of $\mathrm{O}_{3}$ with isoprene, MACR and MVK, respectively. $\mathrm{Y}_{\mathrm{OH}}$ from the reaction of $\mathrm{O}_{3}+\mathrm{isoprene}$ is in excellent agreement with recent measurement by Malkin et al. ${ }^{11}$ and Nguyen et al. ${ }^{2}$ who reported $26 \pm 2$ and $28 \pm 5 \%$, respectively. It is also excellent agreement with the IUPAC recommended value using the set of the literature data reported before $2005, \mathrm{Y}_{\mathrm{OH}}=25 \%$ 5, 12-14. The obtained $\mathrm{OH}$ formation yields for $\mathrm{O}_{3}+\mathrm{MACR}$ and $\mathrm{O}_{3}+\mathrm{MVK}$ have been found to be similar, $\mathrm{Y}_{\mathrm{OH}}=14 \%$, in agreement with the only existing values from Aschmann et al. ${ }^{15}$ and Paulson et al. ${ }^{12}$.

\section{3-2-2 Gas phase stable products formation yields}

Identified oxidation products and corresponding formation yields obtained with different analytical tools are listed in Table 5. Figures 3a-c display the typical IR spectra in the wavenumber region 750-4000 $\mathrm{cm}^{-1}$ obtained during the experiments carried out. Isoprene, MACR, MVK and $\mathrm{SF}_{6}$ have been monitored at 893.8, 2730, 998 and $948 \mathrm{~cm}^{-1}$, respectively. Ozone was measured also by FTIR (at $1042 \mathrm{~cm}^{-1}$ ) in addition to the measurement through the Horiba APOA monitor. Panels A show the spectra of organics $/ \mathrm{O}_{3} / \mathrm{SF}_{6} /$ air mixtures at the start 
of the experiments (after typically $\approx 5$ min of mixing the reactants). Panels B show the spectra after few hours of reactions while panels $\mathrm{C}$ display the spectra of the reactions products after subtraction of the initial organic reactants/O $\mathrm{O}_{3}$ and $\mathrm{SF}_{6}$. Comparison of panels $\mathrm{C}$ with reference spectra of formaldehyde $(\mathrm{HCHO})$, carbon monoxide $(\mathrm{CO})$, formic acid $(\mathrm{HCOOH})$ and methylglyoxal $\left(\mathrm{CH}_{3} \mathrm{C}(\mathrm{O}) \mathrm{C}(\mathrm{O}) \mathrm{H}\right)$ in the remaining panels indicates the formation of these products. In a number of runs, the PTR-Tof-MS (ISO at m/z 69.064, MACR/MVK at m/z 71.0442, cyclohexanone at m/z 81.0463 and 99.0465) and GC-MS (ISO at m/z 67, MACR/MVK at m/z 70, cyclohexanone at $\mathrm{m} / \mathrm{z}$ 98) were also used to monitor the reactants and products.

Figure 4 displays examples of the temporal profiles of the reactants and products from $\mathrm{O}_{3}+\mathrm{ISO}, \mathrm{O}_{3}+\mathrm{MACR}$ and $\mathrm{O}_{3}+\mathrm{MVK}$ obtained by FTIR, PTR-ToF-MS and HCHOmonitor. As shown, the experiments last typically for more than 20 hours each. Table 5 summarizes the experimental conditions and the obtained results along with the literature values. It has to be noted that the experiments presented in this work have been carried out at lower initial reactant concentrations compared to those reported in the previous studies. On the other hand, the experiments were performed in the temperature range 281$295 \mathrm{~K}$ while the literature data were mostly conducted in the range $293-298 \mathrm{~K}$ as shown in Table 5.

For $\mathrm{O}_{3}+\mathrm{ISO}$, we have determined the formation yields for MACR, MVK, HCHO, $\mathrm{CO}$ and $\mathrm{HCOOH}$. The measured MACR and MVK concentrations were corrected for reaction with $\mathrm{O}_{3}$. The yields of MACR and MVK obtained under different experimental conditions (isoprene in excess or $\mathrm{O}_{3}$ in excess with or without $\mathrm{OH}$ scavenger) are in 
general agreement with the literature values ${ }^{2,16-22}$ ranging from $\approx 30$ to $\approx 40 \%$ and $\approx 11$ to $\approx$ $19 \%$, respectively, excluding the data from Paulson et al. ${ }^{18}$ in which higher values have been reported in absence of $\mathrm{OH}$ scavenger. Formaldehyde yield obtained in the present work was found to be between $44 \%$ and $90 \%$ depending on the experimental conditions. $\mathrm{Y}_{\mathrm{HCHO}}=44 \pm 8 \%$ in the runs with isoprene in excess over $\mathrm{O}_{3}$ (in absence of cyclohexane), when $\mathrm{O}_{3}$ was in excess $\mathrm{Y}_{\mathrm{HCHO}}=69 \pm 10 \%$ in the presence of cyclohexane and $90 \pm 2 \%$ in its absence. The observed difference might be an indication of the occurrence of additional sources/sinks to formaldehyde under such conditions. However, as shown in Table 5, the literature data 2, 16, 17, 20, 21 report $\mathrm{Y}_{\mathrm{HCHO}}$ ranging from 55 to $90 \%$. $\mathrm{HCHO}$ may be produced through different mechanisms involving Criegee intermediates as well as the chemistry of the $\mathrm{OH}$ radicals scavengers, cyclohexane or methyl-cyclohexane used in different studies. Ongoing work in our laboratory is devoted to the understanding of the specific formation of formaldehyde through the investigated reactions. The $\mathrm{CO}$ formation yield measured in absence of $\mathrm{OH}$ scavenger and in excess of isoprene, $\mathrm{Y}_{\mathrm{CO}}=26 \pm 6 \%$, is in excellent agreement with the earlier work by Sauer et al. ${ }^{21}$ under the same conditions who reported: $26 \pm 1 \%$. The experiments conducted under excess of $\mathrm{O}_{3}$ in the absence and presence of $\mathrm{OH}$ scavenger led to higher values: $\mathrm{Y}_{\mathrm{CO}}=38 \pm 2$ and $54 \pm 4 \%$, respectively. Formic acid yields, $\mathrm{Y}_{\mathrm{HCOOH}}$, under different experimental conditions were similar, $\mathrm{Y}_{\mathrm{HCOOH}}=4 \pm 1 \%$, which is in excellent agreement with the measurements by Nguyen et al. ${ }^{2}$, Sauer et al. ${ }^{21}$ and Neeb et al. ${ }^{23}$, Y $\mathrm{HCOOH}=5 \pm 1 \%$. Other products have been observed from the ozonolysis of isoprene but not mentioned here such as $\mathrm{H}_{2} \mathrm{O}_{2}$ and hydroxymethyl hydroperoxide (HMHP). This is a part of an ongoing work in our laboratory 
associated to the fate of the Criegee intermediates from a series of alkenes and dienes under atmospheric conditions using HELIOS chamber.

As for $\mathrm{O}_{3}+\mathrm{MACR}$ and $\mathrm{O}_{3}+\mathrm{MVK}$ reactions, the only studies reported so far are those from Grosjean et al. ${ }^{24}$ who conducted the experiments in excess of the organics in the presence of cyclohexane as the $\mathrm{OH}$ scavenger. They have reported yields for formaldehyde $\left(\mathrm{Y}_{\mathrm{HCHO}}=12 \pm 3\right.$ and $\left.5 \%\right)$ and methylglyoxal $\left(\mathrm{Y}_{\mathrm{MGLYOX}}=58 \pm 6\right.$ and $\left.87 \pm 5 \%\right)$ for $\mathrm{O}_{3}+\mathrm{MACR}$ and $\mathrm{O}_{3}+\mathrm{MVK}$, respectively. While a good agreement is observed between the present work and that from Grosjean et al. ${ }^{24}$ on the yields of methylglyoxal, a very large discrepancy exists in the formaldehyde yields as shown in Table 5.

As mentioned above, the ozonolysis of isoprene has been subject to numerous studies under different conditions ( $\mathrm{RH}$, presence or absence of $\mathrm{OH}$ scavengers). The general reaction scheme is similar to the ozonolysis of alkenes. The initial step involves the 1,3dipolar addition of $\mathrm{O}_{3}$ to $\mathrm{C}=\mathrm{C}$ bond (cyclo-addition), which gives rise to the production of a 1,2,3-trioxolane (primary ozonide, POZ). The POZ is a short lived species that undergoes cyclo-reversion to form carbonyl oxides or Criegee intermediates (CIs) and carbonyls (aldehydes and ketones). Two reaction pathways exist for CIs, part of CIs have sufficient internal energy and are subjected to prompt unimolecular reaction to form a hydroperoxide intermediates through $\mathrm{H}$ migration which subsequently decomposes or isomerizes to give $\mathrm{OH}$ radical, carbonyls, $\mathrm{CO}_{2}$ and other products, some of which are potential SOA precursors. The other part of CIs would go through collisional stabilization (SCI). SCI may undergo ring closure to form dioxirane that subsequently decomposes to $\mathrm{HO}_{2}$ radical and other products via "hot acid intermediate". Thermally stabilized SCI may 
also undergo bimolecular reactions with $\mathrm{H}_{2} \mathrm{O}, \mathrm{HCHO}$ and other species in the atmosphere. As isoprene is a conjugated diene, four possible product sets are formed due to two classes of cycloreversion pathway: methacrolein (MACR) and $\mathrm{CH}_{2} \mathrm{OO}$, formaldehyde (HCHO) and MACR oxide, methyl vinyl ketone (MVK) and $\mathrm{CH}_{2} \mathrm{OO}, \mathrm{HCHO}$ and $\mathrm{MVK}$ oxide following the formation of the two types of primary ozonides. MACR, MVK and HCHO are the dominant primary carbonyl products. The chemically activated MACR oxide and MVK oxide subsequently undergo decomposition and isomerization to form a number of products. The measured higher yield of MACR compared to MVK indicates that the $\mathrm{O}_{3}$ reaction with isoprene occurs predominately through the attack on the $\mathrm{CH}_{2}=\mathrm{C}\left(\mathrm{CH}_{3}\right)$ - group.

The mechanisms of the ozonolysis of MACR and MVK have been subject to only one investigation each and from the same group, Grosjean et al. ${ }^{24} \cdot \mathrm{O}_{3}+\mathrm{MACR}$ leads to two channels, $\mathrm{CH}_{3} \mathrm{COCHO}$ (methylglyoxal) $+\left[\mathrm{CH}_{2} \mathrm{COO}\right]^{*}$ and $\mathrm{HCHO}+\left[\mathrm{CH}_{3} \mathrm{COOCHO}\right]^{*}$, while $\mathrm{O}_{3}+\mathrm{MVK}$ leads to $\mathrm{CH}_{3} \mathrm{COCHO}$ (methylglyoxal) $+\left[\mathrm{CH}_{2} \mathrm{COO}\right]^{*}$ and $\mathrm{HCHO}+\left[\mathrm{CH}_{3} \mathrm{COCHOO}\right]^{*}$. In the present work, the experiments were performed in excess of $\mathrm{O}_{3}$ over MACR and MVK. $\mathrm{CO}, \mathrm{HCHO}, \mathrm{HCOOH}$ and methylglyoxal have been observed from both reactions. The presence or absence of scavenger did not affect significantly the measured yields of $\mathrm{CO}$ and $\mathrm{HCHO}$ but $\mathrm{HCOOH}$ and methylglyoxal were below detection limit our instrumentation in the experiments carried out in the presence of cyclohexane as $\mathrm{OH}$ scavenger. Formaldehyde formation yields were significantly higher than that reported from Grosjean et al ${ }^{24}$. who conducted the experiments in excess of organics and added cyclohexane. Methylglyoxal yields obtained in the present work in absence of cyclohexane but using $\mathrm{O}_{3}$ in excess are in agreement with those reported by Grosjean et al. ${ }^{24}$ conducted in the presence of cyclohexane under the 
organics excess conditions. A large discrepancy is observed between the present measurements of the HCHO yields and those reported by Grosjean et al. ${ }^{24}$. Would this be due to some difficulties in analyzing $\mathrm{HCHO}$ in one of the two sets of experiments? Grosjean et al. ${ }^{24}$ have used HPLC analysis while we have used both in-situ FTIR and the sensitive and specific HCHO-AL4021 monitor based on Hantzsch reaction. Ongoing experiments in our laboratory are dedicated to check this possibility.

\section{3-2-3 Secondary organic formation}

A limited number of runs were carried out to investigate the occurrence of secondary organic formation (SOA) during the ozonolysis of isoprene. The main aim of these runs was to check the capabilities of our new built chamber to study SOA formation. Experiments were conducted under the same experimental conditions as those used in the kinetic and products studies (excess of isoprene or $\mathrm{O}_{3}$ and presence or absence of $\mathrm{OH}$ scavenger) in absence of added aerosol seeds. Particle size distributions from 10 to $490 \mathrm{~nm}$ were measured with a scanning mobility particle sizer (SMPS; Model 3934, TSI Inc.). Total particle number concentrations were monitored with condensation particle counter (CPC, TSI, Inc., 3022A) along with a differential mobility analyzer (TSI, Inc., 3081). Table 6 summarizes the experimental conditions and the aerosols yields obtained and Figure 5 displays examples of temporal profiles of SOA formation distribution under various experimental conditions (different initial concentrations of isoprene and $\mathrm{O}_{3}$, with/without $\mathrm{OH}$ radical scavengers). The SOA yield (YSOA) was defined as the ratio of maximum SOA produced $\left(\Delta \mathrm{M}_{0}, \mu \mathrm{g} / \mathrm{m}^{3}\right)$ to the mass concentration consumed $\left(\Delta[\right.$ isoprene $\left.], \mu \mathrm{g} / \mathrm{m}^{3}\right), \mathrm{Y}_{\mathrm{SOA}}=\Delta \mathrm{M}_{0} /(\Delta[$ isoprene $])$ as Kleindienst et al. ${ }^{25}$. A density of $1 \mathrm{~g} / \mathrm{cm}^{3}$ was applied to convert the integrated SOA volume to mass concentration. The 
chamber wall loss of SOA was taken into account by applying a first order loss rate obtained from the decay of the particle volume concentration after reaching its maximum value for each individual experiment.

Figures 5 and 6 show, respectively, the prompt formation of SOA with the initiation of the reaction and their growth as function of the consumed isoprene under the three experimental conditions used in this study. The SOA yields obtained depend on the experimental conditions as shown in Table 6. In excess of isoprene and absence of cyclohexane, the SOA yield was $Y_{\mathrm{SOA}} \approx 3.5 \pm 2.5 \%$, higher that obtained during the experiments conducted in excess of ozone in both, without and with cyclohexane added, $\mathrm{YSOA}_{\mathrm{SO}} \approx 1.0 \pm 0.2 \%$ and $<1 \%$, respectively. These data have to be considered as preliminary and more experiments need to be carried out under wider experimental conditions in order to characterize more precisely the SOA yields. However, it has to be noted that the earlier studies conducted on the aerosol formation from the ozonolysis of isoprene have reported formation yields of $\approx 1 \%$ (Kleindienst et al.) ${ }^{25}$ or less (e.g. Jang et al. 2002, Czoschke et al. 2003) ${ }^{26,27}$ dependind on the experimental conditions.

\section{Conclusions and future work}

A series of experiments were carried out using the new built simulation chamber, HELIOS, to check its capacities in investigating complex gas phase processes. The characteristics of HELIOS enable us to conduct studies under ambient temperatures, typically around $\approx 10{ }^{\circ} \mathrm{C}$ $(\approx 283 \mathrm{~K})$ from late autumn to early spring in the Orleans (France) area. The analytical equipment at the facility makes investigations under wide range concentrations of the reactants and products, from ppb to ppm levels, possible. In the current paper, we describe a first set of 
data obtained on the ozonolysis of isoprene, one of the most important VOCs in the atmosphere, and its main oxidation products, methacrolein and methyl vinyl ketone. Reactions rate constants for the reactions of ozone with the above organic species have been measured in the ambient temperature range $281-295 \mathrm{~K}$ under different experimental conditions such as initial reactants concentrations, excess of $\mathrm{O}_{3}$ over the organics and visversa in presence or absence of $\mathrm{OH}$ scavenger. The obtained values for ko3+organic have been found in good agreement with the recommended values calculated using the Arrhenius expressions from IUPAC panel.

A section of the present work is dedicated to the $\mathrm{OH}$ radical and stable products formation from the investigated reactions. $\mathrm{OH}$ radical formation yield is reported for the three reactions, $\mathrm{Y}_{\mathrm{OH}}=24 \pm 2 \%$ from $\mathrm{O}_{3}+\mathrm{ISO}, 14.3 \pm 3.5 \%$ from $\mathrm{O}_{3}+\mathrm{MACR}$ and $13.4 \pm 4.1 \%$

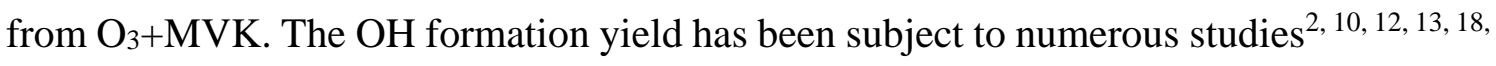
$20,22,28-30$. Our measured value is in excellent agreement with the preferred value from IUPAC panel, $\mathrm{Y}_{\mathrm{OH}}=25 \%$. The $\mathrm{OH}$ formation yield from $\mathrm{O}_{3}+\mathrm{MACR}$ and $\mathrm{O}_{3}+\mathrm{MVK}$ have been measured earlier in a very limited number of studies. The value obtained here for $\mathrm{O}_{3}+\mathrm{MACR}$ reaction is in agreement with that from Aschmann et al. ${ }^{15}, 20^{+10}-13$ and that for $\mathrm{O}_{3}+\mathrm{MVK}$ is in excellent agreement with the one measured by Aschmann et al. ${ }^{15}, 18 \pm 8 \%$ and by Paulson et al. ${ }^{12} 16 \pm 5 \%$. Yields for series stable oxidation products are reported and compared to the literature data. We report here formation yields for MACR, MVK, $\mathrm{HCHO}, \mathrm{HCOOH}$ and $\mathrm{CO}$. The general trends of the obtained values are in line with the recommended IUPAC values for $\mathrm{O}_{3}$ reaction with isoprene. The product yields obtained 
for the reactions of $\mathrm{O}_{3}$ with MACR and MVK are also compared to those from the single available study on these reactions from Grosjean et al. ${ }^{24}$.

In addition to the gas phase product, a limited number of runs were performed to estimate the SOA formation yields from ozonolysis of isoprene which showed that the yields values depend on the initial experimental conditions. However, the experiments conducted in presence of $\mathrm{OH}$ scavenger $(\leq 1 \%)$ were lower than the ones in its absence $(1-3.5 \%)$ which indicates a potential contribution of $\mathrm{OH}$ chemistry in the SOA production observed.

Work is ongoing in our laboratory to investigate the complete chemistry of the studied reactions by using wider set of analytical equipment for the analysis of unstable species as well as peroxides and hydroperoxydes. To this aim, new instrumentation such as API-ToF-CIMS and UHPLC-MS have been recently connected to the HELIOS chamber for the analysis of the missing organic fraction as well as characterizing the aerosol composition. The chamber is large enough to enable the collection of sufficient aerosol mass for chemical analysis In addition, the CNRS-Orleans CIMS dedicated to the $\mathrm{OH}$ and $\mathrm{HO}_{2}$ measurements will be used to conduct the ongoing work.

\section{Acknowledgements}

This work is supported by Labex Voltaire (ANR-10-LABX-100-01), ANR (13-BS060002-01, COGNAC), ARD PIVOTS program (supported by the Centre-Val de Loire regional council), and the European Union's Horizon 2020 research and innovation programme under grant agreement No 730997 "Eurochamp2020". RY is grateful to the China Scholarship Council for the financial support. 
1. R. Atkinson and J. Arey, Chemical reviews, 2003, 103, 4605-4638.

2. T. B. Nguyen, G. S. Tyndall, J. D. Crounse, A. P. Teng, K. H. Bates, R. H. Schwantes, M. M. Coggon, L. Zhang, P. Feiner, D. O. Milller, K. M. Skog, J. C. Rivera-Rios, M. Dorris, K. F. Olson, A. Koss, R. J. Wild, S. S. Brown, A. H. Goldstein, J. A. de Gouw, W. H. Brune, F. N. Keutsch, J. H. Seinfeld and P. O. Wennberg, Physical Chemistry Chemical Physics, 2016, 18, 10241-10254.

3. M. Sipila, T. Jokinen, T. Berndt, S. Richters, R. Makkonen, N. M. Donahue, R. L. Mauldin, III, T. Kurten, P. Paasonen, N. Sarnela, M. Ehn, H. Junninen, M. P. Rissanen, J. Thornton, F. Stratmann, H. Herrmann, D. R. Worsnop, M. Kulmala, V. M. Kerminen and T. Petaja, Atmospheric Chemistry and Physics, 2014, 14, 12143-12153.

4. M. J. Newland, A. R. Rickard, L. Vereecken, A. Muñoz, M. Ródenas and W. J. Bloss, Atmos. Chem. Phys. Discuss., 2015, 15, 8839-8881.

5. R. Atkinson, D. L. Baulch, R. A. Cox, J. N. Crowley, R. F. Hampson, R. G. Hynes, M. E. Jenkin, M. J. Rossi, J. Troe and I. Subcommittee, Atmos. Chem. Phys., 2006, 6, 3625-4055.

6. M. Müller, T. Mikoviny, W. Jud, B. D'Anna and A. Wisthaler, Chemometrics and Intelligent Laboratory Systems, 2013, 127, 158-165.

7. C. Schäfer, O. Horie, J. N. Crowley and G. K. Moortgat, Geophysical Research Letters, 1997, 24, 1611-1614.

8. A. A. Chew and R. Atkinson, Journal of Geophysical Research: Atmospheres, 1996, 101, 2864928653.

9. M. S. Alam, A. R. Rickard, M. Camredon, K. P. Wyche, T. Carr, K. E. Hornsby, P. S. Monks and W. J. Bloss, The Journal of Physical Chemistry A, 2013, 117, 12468-12483.

10. R. Atkinson and S. M. Aschmann, Environmental Science \& Technology, 1993, 27, 1357-1363.

11. T. L. Malkin, A. Goddard, D. E. Heard and P. W. Seakins, Atmos. Chem. Phys., 2010, 10, 14411459.

12. S. E. Paulson, M. Chung, A. D. Sen and G. Orzechowska, Journal of Geophysical Research, 1998, 103, 25533.

13. P. Neeb and G. K. Moortgat, The Journal of Physical Chemistry A, 1999, 103, 9003-9012.

14. J. H. Kroll, T. F. Hanisco, N. M. Donahue, K. L. Demerjian and J. G. Anderson, Geophysical Research Letters, 2001, 28, 3863-3866.

15. S. M. Aschmann, J. Arey and R. Atkinson, Atmospheric Environment, 1996, 30, 2939-2943.

16. R. M. Kamens, M. W. Gery, H. E. Jeffries, M. Jackson and E. I. Cole, International Journal of Chemical Kinetics, 1982, 14, 955-975.

17. H. Niki, P. D. Maker, C. M. Savage and L. P. Breitenbach, Environmental Science \& Technology, $1983,17,312 \mathrm{~A}-322 \mathrm{~A}$.

18. S. E. Paulson, R. C. Flagan and J. H. Seinfeld, International Journal of Chemical Kinetics, 1992, 24, 103-125.

19. S. M. Aschmann and R. Atkinson, Environmental Science \& Technology, 1994, 28, 1539-1542.

20. R. Gutbrod, E. Kraka, R. N. Schindler and D. Cremer, Journal of the American Chemical Society, 1997, 119, 7330-7342.

21. F. Sauer, C. Schäfer, P. Neeb, O. Horie and G. K. Moortgat, Atmospheric Environment, 1999, 33, 229-241.

22. R. lannone, R. Koppmann and J. Rudolph, Atmospheric Environment, 2010, 44, 4135-4141.

23. P. Neeb, F. Sauer, O. Horie and G. K. Moortgat, Atmospheric Environment, 1997, 31, 14171423. 
24. D. Grosjean, E. L. Williams and E. Grosjean, Environmental Science \& Technology, 1993, 27, 830-840.

25. T. E. Kleindienst, M. Lewandowski, J. H. Offenberg, M. Jaoui and E. O. Edney, Geophysical Research Letters, 2007, 34, L01805.

26. M. Jang, N. M. Czoschke, S. Lee and R. M. Kamens, Science, 2002, 298, 814-817.

27. N. M. Czoschke, M. Jang and R. M. Kamens, Atmospheric Environment, 2003, 37, 4287-4299.

28. N. M. Donahue, J. H. Kroll, J. G. Anderson and K. L. Demerjian, Geophysical Research Letters, 1998, 25, 59-62.

29. A. R. Rickard, D. Johnson, C. D. McGill and G. Marston, Journal of Physical Chemistry A, 1999, 103, 7656-7664.

30. A. G. Lewin, D. Johnson, D. W. Price and G. Marston, Physical Chemistry Chemical Physics, 2001, 3, 1253-1261. 

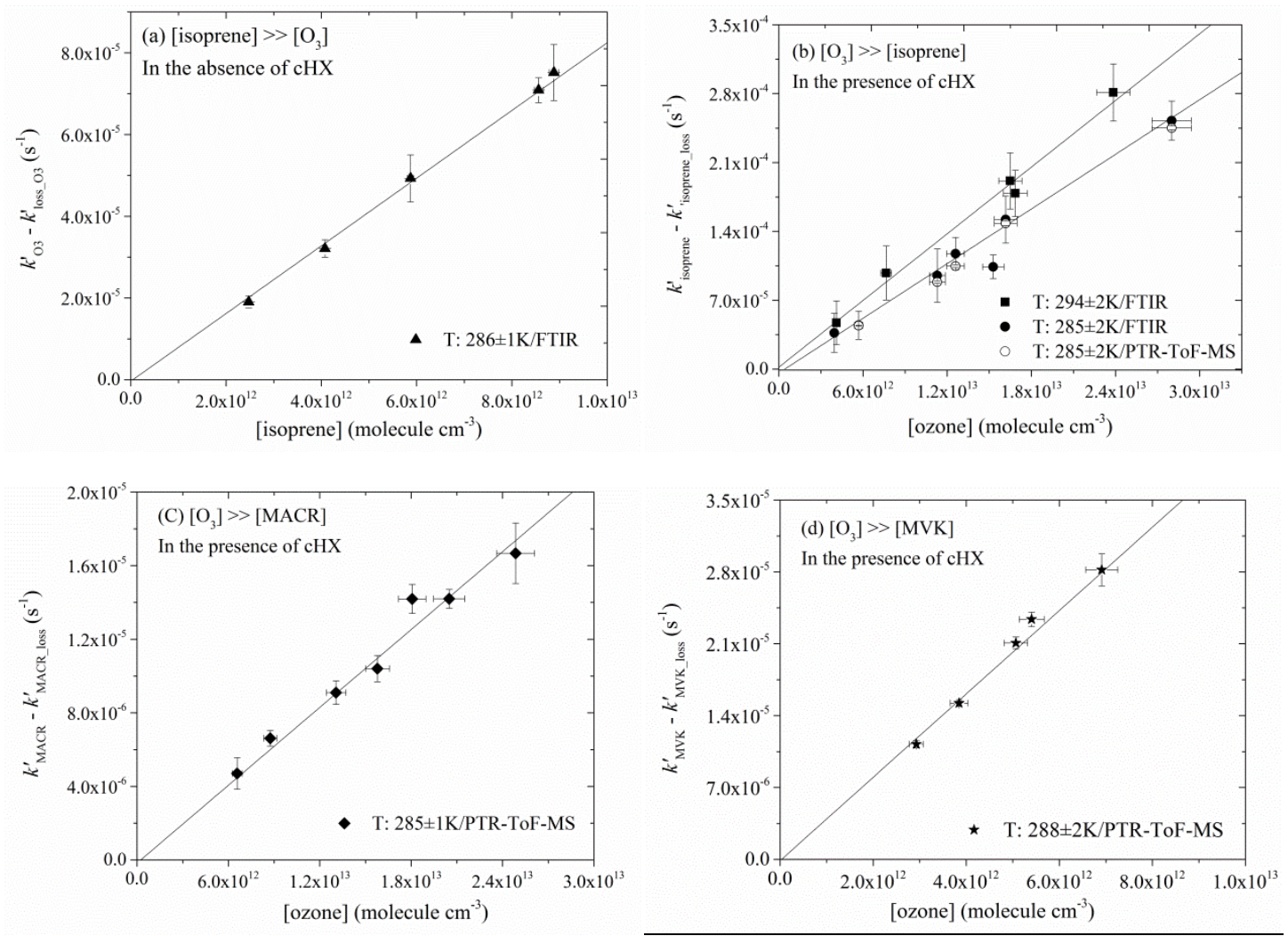

Figures $1(\mathrm{a}-\mathrm{d})$ Plot of decay rate $\left(\mathrm{k}^{\prime}-\mathrm{k}^{\prime} \mathrm{)}\right)$ as a function of $\left[\mathrm{O}_{3}\right]_{0}$ or [Isoprene $]_{0}$, (a) [isoprene] in excess over $\left[\mathrm{O}_{3}\right]$ in the absence of $\mathrm{cHX}$; (b) $\left[\mathrm{O}_{3}\right]$ in excess over [isoprene] in the presence of $\mathrm{cHX} ;(\mathrm{c})\left[\mathrm{O}_{3}\right]$ in excess over $[\mathrm{MACR}]$ in the presence of $\mathrm{cHX}$; (d) $\left[\mathrm{O}_{3}\right]$ in excess over $[\mathrm{MVK}]$ in the presence of $\mathrm{cHX}$. 

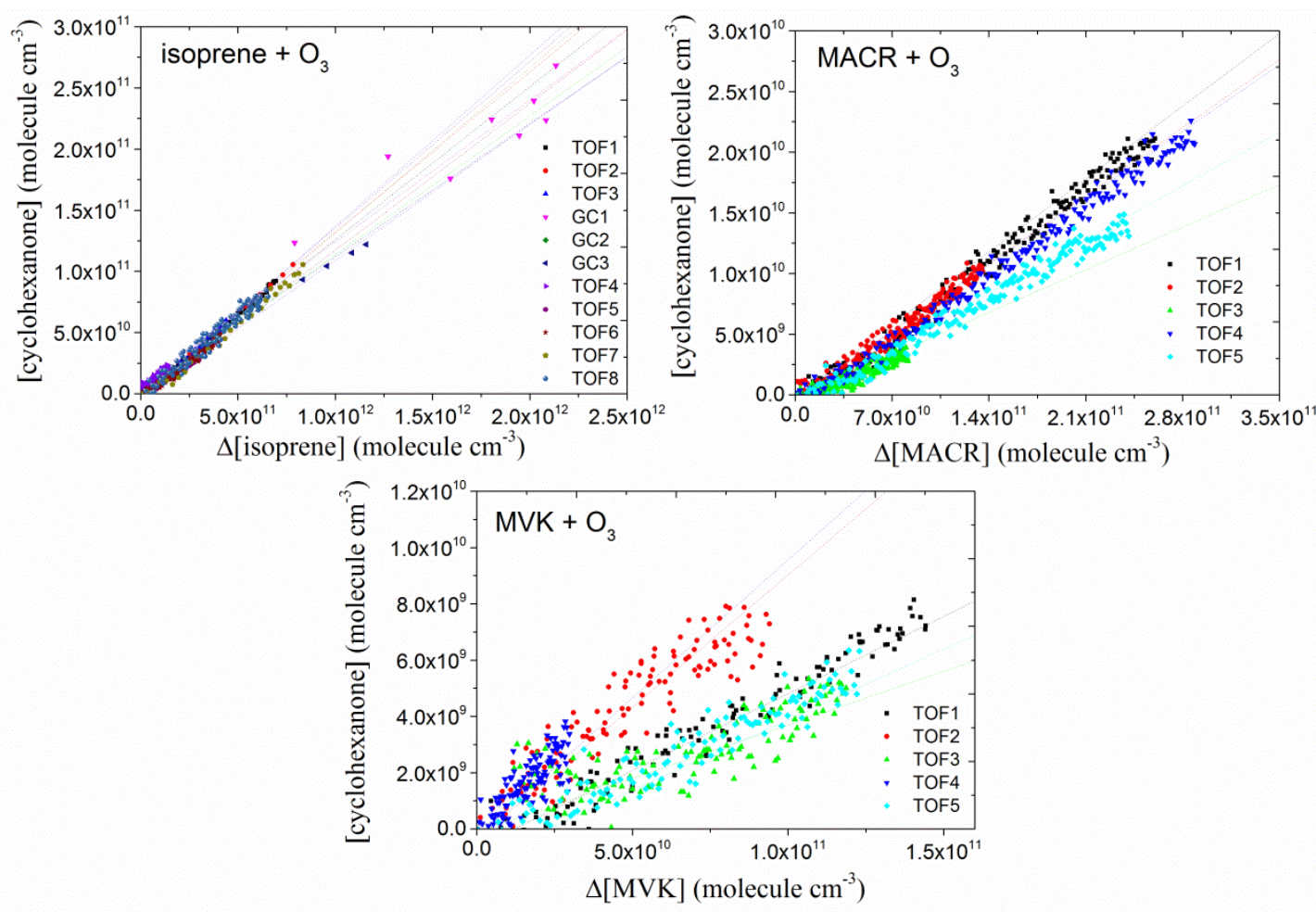

Figure 2: Plot of cyclohexanone concentration with respect to consumed isoprene, MACR and MVK (TOF, GC: data obtained using PTR-ToF-MS or GC-MS, respectively) 


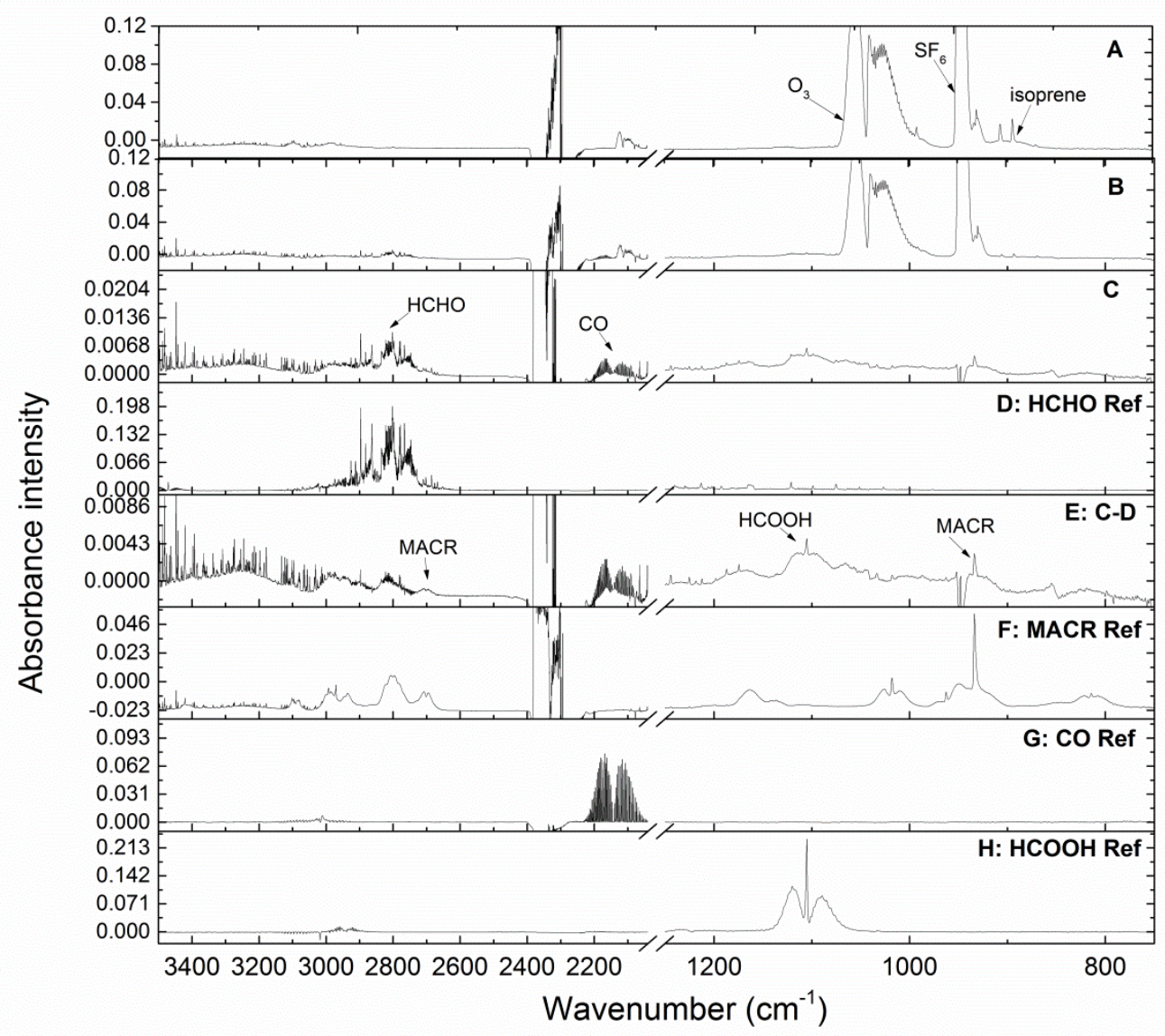

Figure $3 \mathrm{a}-\mathrm{O}_{3}+$ isoprene: FTIR spectra acquired after 5 minutes of reaction (A) and 2 hours (B), panel $\mathrm{C}=\mathrm{B}-\mathrm{A}$ (to identify the products), panel $\mathrm{D}=$ is the $\mathrm{HCHO}$ reference spectrum. Panel E shows the residual spectrum after subtraction of features attributable to formaldehyde. Reference spectra are shown for MACR (F), CO (G), and $\mathrm{HCOOH}(\mathrm{H})$. 


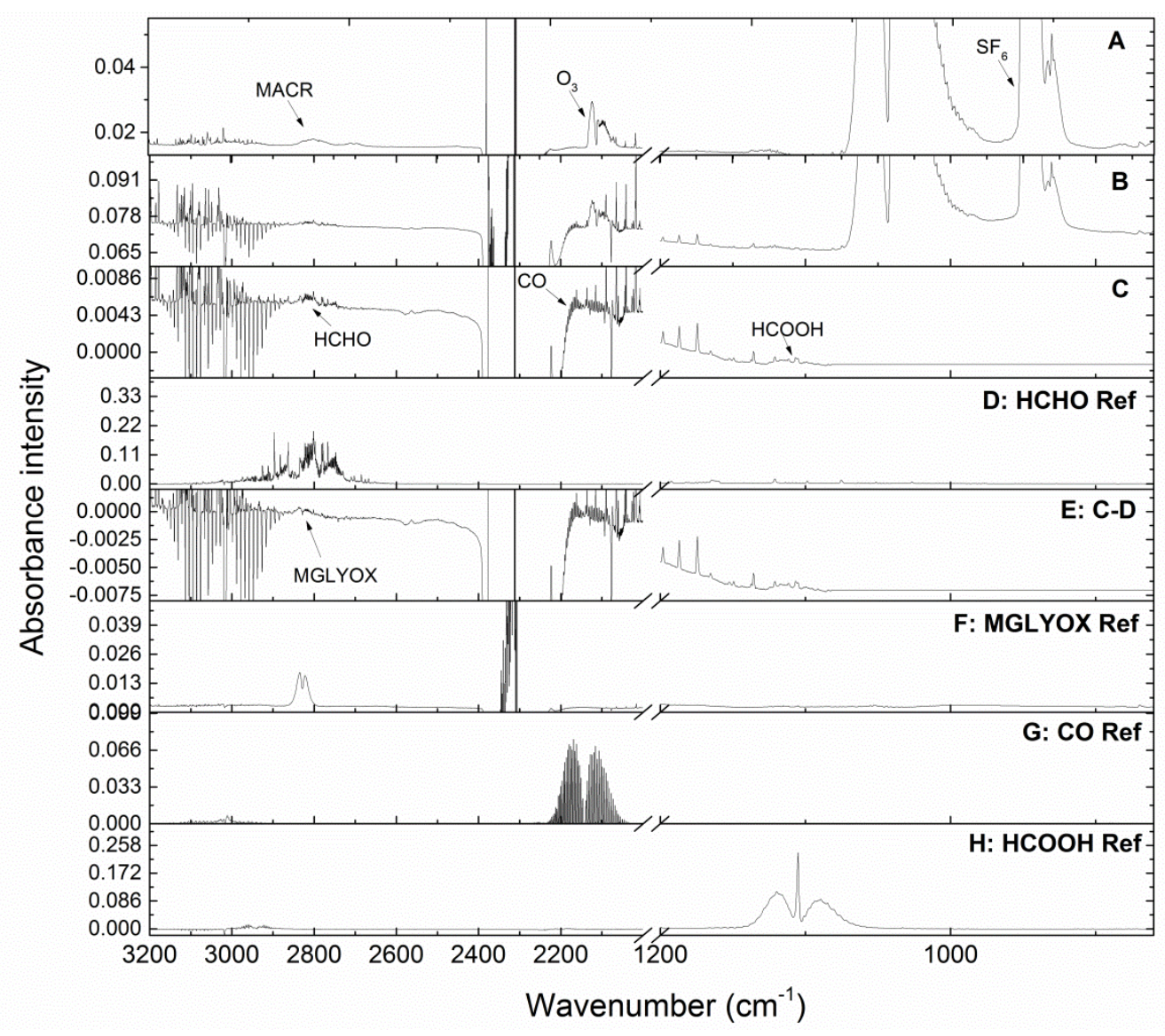

Figure $3 b-\mathrm{O}_{3}+$ MACR: FTIR spectra acquired after 5 minutes of reaction (A) and 5 hours (B), panel C = B-A (to identify the products). Panel D is the HCHO reference spectrum. Panel E shows the residual spectrum after subtraction of features attributable to formaldehyde. Reference spectra are shown for methylglyoxal (F), $\mathrm{CO}(\mathrm{G})$, and $\mathrm{HCOOH}(\mathrm{H})$. 


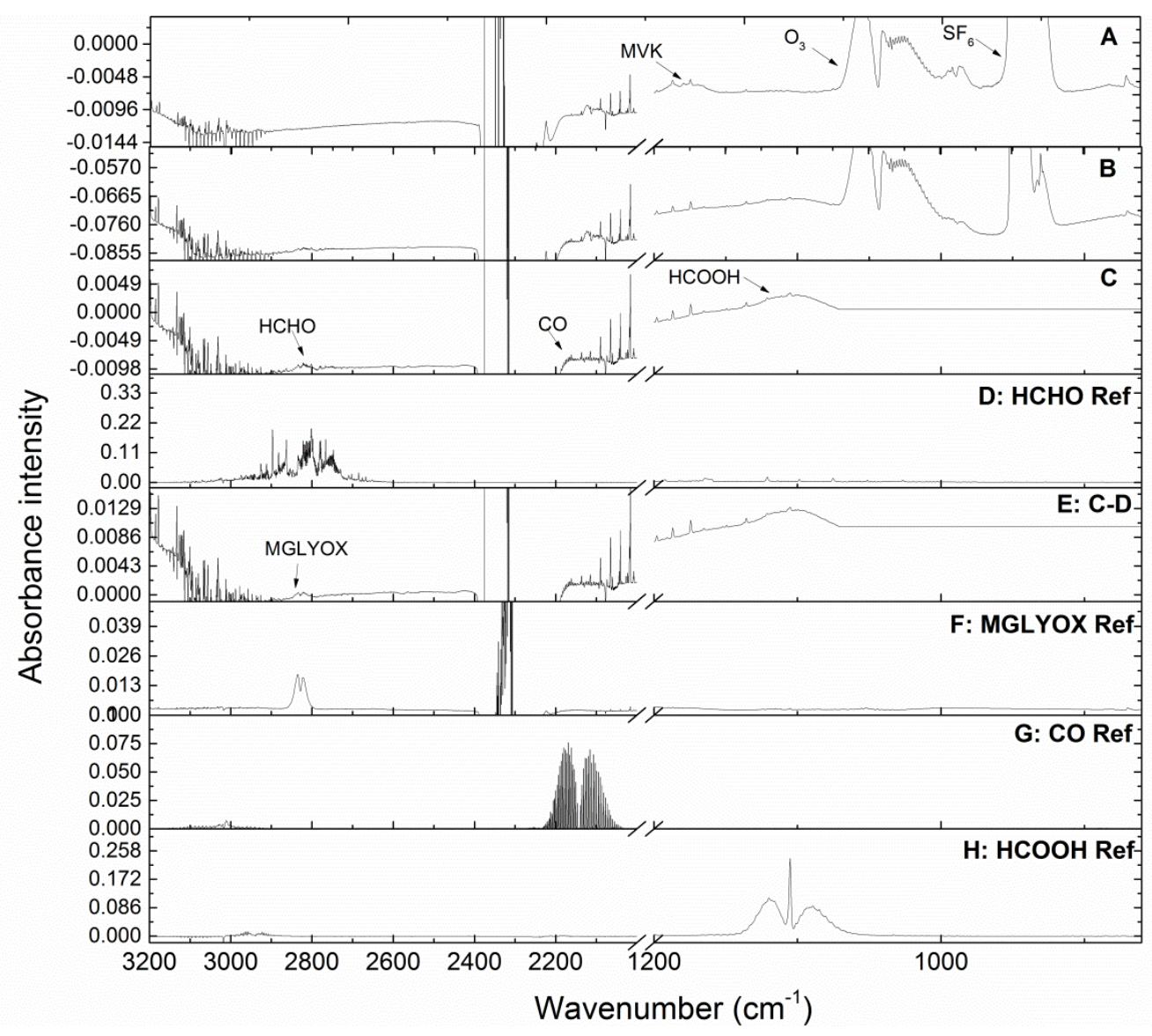

Figure $3 c-\mathrm{O}_{3}+$ MVK: FTIR spectra acquired after 5 minutes of reaction (A) and 5 hours (B), panel $\mathrm{C}=\mathrm{B}-\mathrm{A}$ (to identify the products). Panel D is the HCHO reference spectrum. Panel E shows the residual spectrum after subtraction of features attributable to formaldehyde. Reference spectra are shown for methylglyoxal (F), CO (G), and $\mathrm{HCOOH}(\mathrm{H})$. 

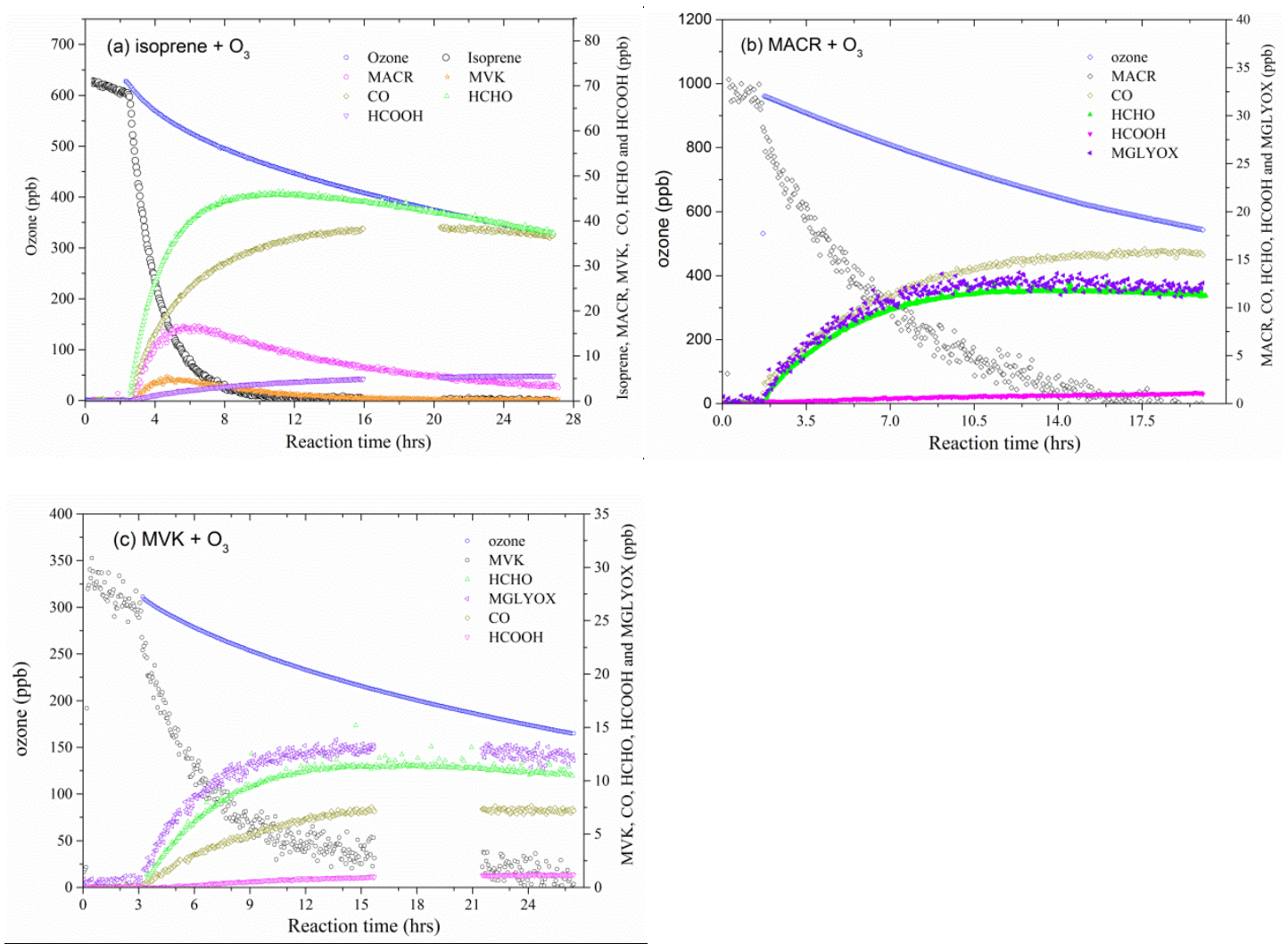

Figure 4 -Temporal profiles of reactants (isoprene/MACR/MVK, $\mathrm{O}_{3}$ ) and observed products in the reactions of $\mathrm{O}_{3}$-isoprene (a), $\mathrm{O}_{3}$-MACR (b), $\mathrm{O}_{3}$-MVK (c). Isoprene, $\mathrm{O}_{3}, \mathrm{CO}, \mathrm{HCOOH}$ and MGLYOX were monitored by FTIR, MACR and MVK were measured by PTR-ToFMS, and HCHO was monitored by Aerolaser-4021. 

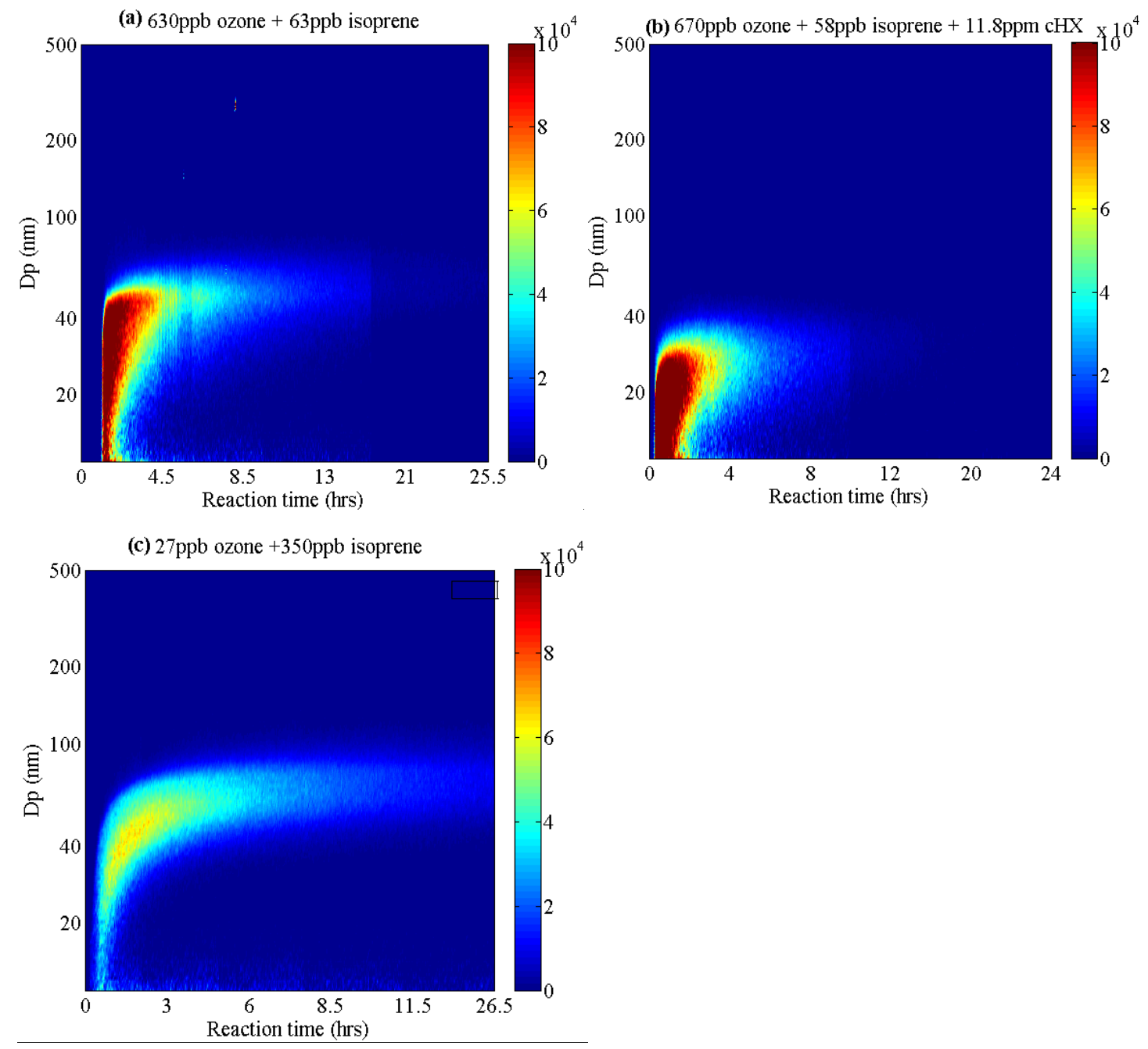

Figure 5 - Examples of temporal profiles of SOA formation (number concentration) under various experimental conditions including different initial concentrations of isoprene and $\mathrm{O}_{3}$, with/without $\mathrm{OH}$ radical scavengers. 


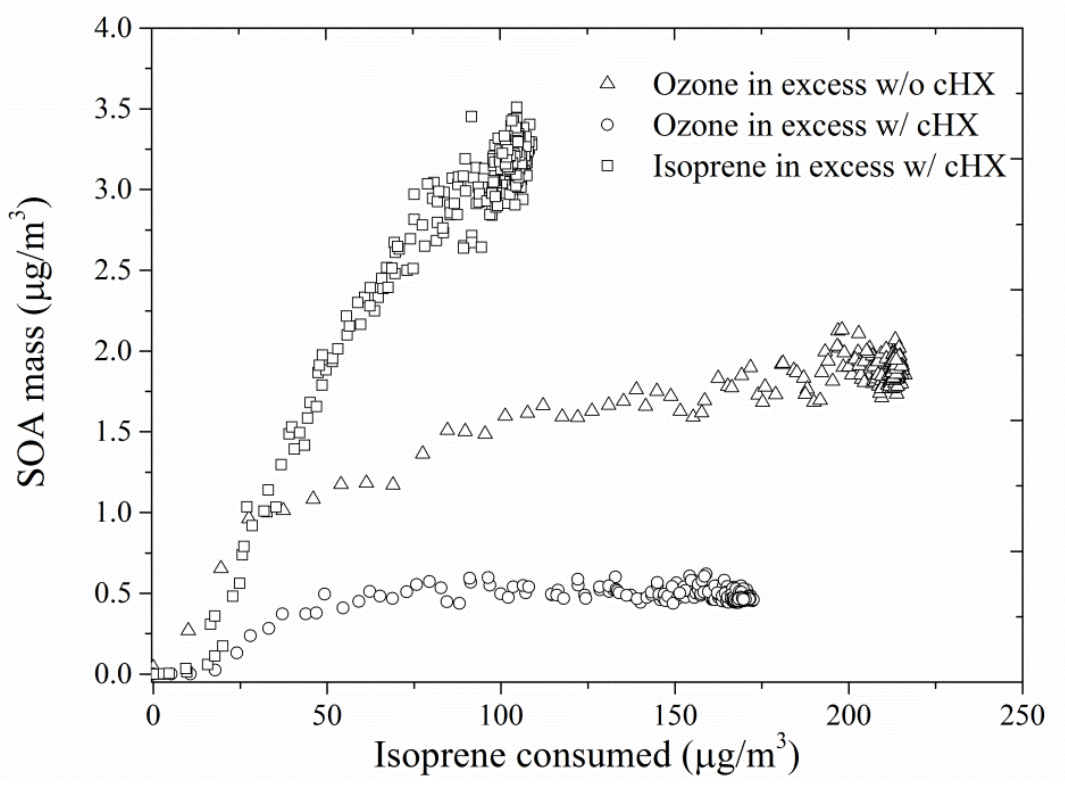

Figure 6 - SOA growth as a function of consumed isoprene concentration under different experimental conditions. 
Table 1: Reaction of $\mathrm{O}_{3}$ with isoprene: Initial experimental conditions and results from the kinetic studies

\begin{tabular}{|c|c|c|c|c|c|}
\hline $\begin{array}{c}\text { Experimental } \\
\text { conditions }\end{array}$ & $\mathrm{T}(\mathrm{K})$ & $\begin{array}{c}{\left[\mathrm{O}_{3}\right]_{0}} \\
\text { (molecule } \mathrm{cm}^{-3} \text { ) }\end{array}$ & $\begin{array}{c}{[\text { Isoprene }]_{0}} \\
\left(\text { molecule } \mathrm{cm}^{-3}\right)\end{array}$ & $\begin{array}{l}{[\text { Cyclohexane }]_{0}} \\
\left(\text { molecule } \mathrm{cm}^{-3}\right)\end{array}$ & $\begin{array}{c}k^{\prime}-k_{0}^{\prime}( \pm 1 \delta) \\
\left(\times 10^{-5} \mathrm{~s}^{-1}\right)\end{array}$ \\
\hline \multirow{6}{*}{$\begin{array}{l}\text { Isoprene in } \\
\text { excess, } \\
\text { without } \mathrm{OH} \\
\text { scavenger }\end{array}$} & $286 \pm 1$ & $3.4 \times 10^{12}$ & $24.7 \times 10^{11}$ & 0 & $1.9 \pm 0.1$ \\
\hline & $285 \pm 1$ & $5.6 \times 10^{12}$ & $40.8 \times 10^{11}$ & 0 & $3.2 \pm 0.2$ \\
\hline & $285 \pm 1$ & $5.4 \times 10^{12}$ & $58.7 \times 10^{11}$ & 0 & $4.9 \pm 0.6$ \\
\hline & $285 \pm 1$ & $9.0 \times 10^{12}$ & $85.6 \times 10^{11}$ & 0 & $7.1 \pm 0.3$ \\
\hline & $283 \pm 1$ & $6.9 \times 10^{12}$ & $88.8 \times 10^{11}$ & 0 & $7.5 \pm 0.7$ \\
\hline & $285 \pm 1$ & \multicolumn{4}{|c|}{ Average: $\mathrm{k}=(8.6 \pm 0.5) \times 10^{-18} \mathrm{~cm}^{3}$ molecule $\mathrm{s}^{-1}$} \\
\hline \multirow{15}{*}{$\begin{array}{c}\mathrm{O}_{3} \text { in excess, } \\
\text { with } \mathrm{OH} \\
\text { scavenger }\end{array}$} & $294 \pm 1$ & $4.1 \times 10^{12}$ & $3.9 \times 10^{11}$ & $8.1 \times 10^{13}$ & $4.7 \pm 2.2$ \\
\hline & $295 \pm 1$ & $7.7 \times 10^{12}$ & $6.6 \times 10^{11}$ & $15.9 \times 10^{13}$ & $9.8 \pm 2.7 / 9.5 \pm 0.1^{\mathrm{a}}$ \\
\hline & $295 \pm 1$ & $16.5 \times 10^{12}$ & $14.4 \times 10^{11}$ & $18.4 \times 10^{13}$ & $19.1 \pm 2.9 / 19.5 \pm 0.2^{\mathrm{a}}$ \\
\hline & $291 \pm 1$ & $16.9 \times 10^{12}$ & $14.6 \times 10^{11}$ & $29.5 \times 10^{13}$ & $17.9 \pm 2.4$ \\
\hline & $294 \pm 1$ & $23.8 \times 10^{12}$ & $21.1 \times 10^{11}$ & $45.1 \times 10^{13}$ & $28.1 \pm 2.9$ \\
\hline & $294 \pm 2$ & \multicolumn{4}{|c|}{ Average: $\mathrm{k}=(11.3 \pm 1.7) \times 10^{-18} \mathrm{~cm}^{3}$ molecule $\mathrm{s}^{-1}$} \\
\hline & $286 \pm 1$ & $4.0 \times 10^{12}$ & $2.6 \times 10^{11}$ & $7.0 \times 10^{13}$ & $3.7 \pm 2.0$ \\
\hline & $282 \pm 1$ & $5.7 \times 10^{12}$ & $3.9 \times 10^{11}$ & $9.4 \times 10^{13}$ & $4.5 \pm 1.4 / 4.4 \pm 0.1^{\mathrm{a}}$ \\
\hline & $284 \pm 1$ & $11.3 \times 10^{12}$ & $5.6 \times 10^{11}$ & $12.8 \times 10^{13}$ & $9.5 \pm 2.7 / 8.9 \pm 0.2^{\mathrm{a}}$ \\
\hline & $286 \pm 1$ & $12.6 \times 10^{12}$ & $11.2 \times 10^{11}$ & $15.0 \times 10^{13}$ & $11.7 \pm 1.7 / 10.5 \pm 0.3^{\mathrm{a}}$ \\
\hline & $284 \pm 1$ & $16.2 \times 10^{12}$ & $8.4 \times 10^{11}$ & $22.4 \times 10^{13}$ & $15.2 \pm 2.4 / 14.8 \pm 0.5^{\mathrm{a}}$ \\
\hline & $283 \pm 1$ & $28.0 \times 10^{12}$ & $23.7 \times 10^{11}$ & $51.8 \times 10^{13}$ & $25.2 \pm 2.0 / 24.5 \pm 0.5^{\mathrm{a}}$ \\
\hline & $285 \pm 2$ & \multicolumn{4}{|c|}{ Average: $\mathrm{k}=(9.3 \pm 0.7) \times 10^{-18} \mathrm{~cm}^{3}$ molecule $\mathrm{s}^{-1}$} \\
\hline & $278 \pm 1$ & $15.3 \times 10^{12}$ & $13.8 \times 10^{11}$ & $24.7 \times 10^{13}$ & $10.4 \pm 1.2 / 10.1 \pm 0.2^{\mathrm{a}}$ \\
\hline & & \multicolumn{4}{|c|}{$\mathrm{k}=(6.7 \pm 1.0) \times 10^{-18} \mathrm{~cm}^{3}$ molecule $\mathrm{e}^{-1} \mathrm{~s}^{-1}$} \\
\hline \multirow{13}{*}{$\begin{array}{c}\mathrm{O}_{3} \text { in excess, } \\
\text { without } \mathrm{OH} \\
\text { scavenger }\end{array}$} & $283 \pm 1$ & $3.3 \times 10^{12}$ & $4.3 \times 10^{11}$ & 0 & $3.2 \pm 0.6$ \\
\hline & $283 \pm 1$ & $4.0 \times 10^{12}$ & $3.4 \times 10^{11}$ & 0 & $5.0 \pm 0.7$ \\
\hline & $285 \pm 1$ & $11.9 \times 10^{12}$ & $10.7 \times 10^{11}$ & 0 & $13.1 \pm 1.1$ \\
\hline & $283 \pm 1$ & $12.8 \times 10^{12}$ & $5.8 \times 10^{11}$ & 0 & $14.5 \pm 2.0 / 13.5 \pm 0.3^{\mathrm{a}}$ \\
\hline & $285 \pm 1$ & $15.8 \times 10^{12}$ & $16.3 \times 10^{11}$ & 0 & $17.1 \pm 2.0 / 17.0 \pm 0.4^{\mathrm{a}}$ \\
\hline & $284 \pm 1$ & \multicolumn{4}{|c|}{ Average: $\mathrm{k}=(10.8 \pm 1.1) \times 10^{-18} \mathrm{~cm}^{3}$ molecule $\mathrm{s}^{-1}$} \\
\hline & $280 \pm 1$ & $10.7 \times 10^{12}$ & $5.3 \times 10^{11}$ & 0 & $10.0 \pm 2.7 / 9.8 \pm 0.2^{\mathrm{a}}$ \\
\hline & $282 \pm 1$ & $12.6 \times 10^{12}$ & $12.3 \times 10^{11}$ & 0 & $12.3 \pm 1.5$ \\
\hline & $279 \pm 1$ & $14.2 \times 10^{12}$ & $6.9 \times 10^{11}$ & 0 & $13.9 \pm 3.1$ \\
\hline & $281 \pm 1$ & $20.3 \times 10^{12}$ & $9.9 \times 10^{11}$ & 0 & $20.0 \pm 2.6 / 19.2 \pm 0.4^{\mathrm{a}}$ \\
\hline & $281 \pm 1$ & $25.3 \times 10^{12}$ & $23.0 \times 10^{11}$ & 0 & $24.1 \pm 2.1$ \\
\hline & $281 \pm 1$ & \multicolumn{4}{|c|}{ Average: $\mathrm{k}=(9.7 \pm 0.7) \times 10^{-18} \mathrm{~cm}^{3}$ molecule $\mathrm{e}^{-1} \mathrm{~s}^{-1}$} \\
\hline & $288 \pm 1$ & $21.3 \times 10^{12}$ & \multicolumn{3}{|c|}{$\mathrm{k}=(11.9 \pm 1.8) \times 10^{-18} \mathrm{~cm}^{3}$ molecule $\mathrm{s}^{-1}$} \\
\hline
\end{tabular}

${ }^{\text {a }}$ value from PTR-ToF-MS 
Table 2: Reactions of $\mathrm{O}_{3}$ with Methacrolein (MACR): Initial experimental conditions and results from the kinetic studies

\begin{tabular}{|c|c|c|c|c|c|}
\hline & $\mathrm{T}(\mathrm{K})$ & $\begin{array}{c}{[\text { ozone }]_{0}} \\
\left(\text { molecule } \mathrm{cm}^{-3}\right)\end{array}$ & $\begin{array}{c}{[\mathrm{MACR}]_{0}} \\
\left(\text { molecule } \mathrm{cm}^{-3}\right)\end{array}$ & $\begin{array}{l}{[\text { cyclohexane }]_{0}} \\
\left(\text { molecule } \mathrm{cm}^{-3}\right)\end{array}$ & $\begin{array}{c}k^{\prime}-k_{\text {loss }}^{\prime}( \pm 1 \delta) \\
\left(\times 10^{-6} \mathrm{~s}^{-1}\right)\end{array}$ \\
\hline \multirow{9}{*}{$\begin{array}{l}\mathrm{O}_{3} \text { in excess } \\
\text { with } \mathrm{OH} \\
\text { scavenger }\end{array}$} & $285 \pm 1$ & $24.9 \times 10^{12}$ & $9.8 \times 10^{11}$ & $18.9 \times 10^{13}$ & $16.7 \pm 1$ \\
\hline & $284 \pm 1$ & $15.8 \times 10^{12}$ & $7.7 \times 10^{11}$ & $18.4 \times 10^{13}$ & $10.4 \pm 0.7$ \\
\hline & $285 \pm 1$ & $13.1 \times 10^{12}$ & $5.3 \times 10^{11}$ & $17.3 \times 10^{13}$ & $9.1 \pm 0.6$ \\
\hline & $285 \pm 1$ & $20.5 \times 10^{12}$ & $32.3 \times 10^{11}$ & $29.8 \times 10^{13}$ & $14.2 \pm 0.5$ \\
\hline & $285 \pm 1$ & $6.6 \times 10^{12}$ & $2.8 \times 10^{11}$ & $27.1 \times 10^{13}$ & $4.7 \pm 0.8$ \\
\hline & $285 \pm 1$ & $8.8 \times 10^{12}$ & $2.4 \times 10^{11}$ & $29.0 \times 10^{13}$ & $6.6 \pm 0.4$ \\
\hline & $285 \pm 1$ & \multicolumn{4}{|c|}{ Average: $\mathrm{k}=(7.1 \pm 0.6) \times 10^{-19} \mathrm{~cm}^{3}$ molecule $\mathrm{s}^{-1} \mathrm{~s}^{-1}$} \\
\hline & $287 \pm 1$ & $18.1 \times 10^{12}$ & $10.4 \times 10^{11}$ & $28.5 \times 10^{13}$ & $14.2 \pm 0.8$ \\
\hline & & \multicolumn{4}{|c|}{$\mathrm{k}=(7.9 \pm 1.2) \times 10^{-19} \mathrm{~cm}^{3}$ molecule ${ }^{-1} \mathrm{~s}^{-1}$} \\
\hline \multirow{12}{*}{$\begin{array}{c}\mathrm{O}_{3} \text { in excess } \\
\text { without } \mathrm{OH} \\
\text { scavenger }\end{array}$} & $280 \pm 1$ & $7.1 \times 10^{12}$ & $5.9 \times 10^{11}$ & 0 & $8.0 \pm 0.4$ \\
\hline & $280 \pm 1$ & $5.1 \times 10^{12}$ & $2.6 \times 10^{11}$ & 0 & $5.5 \pm 0.3$ \\
\hline & $284 \pm 1$ & $8.2 \times 10^{12}$ & $7.6 \times 10^{11}$ & 0 & $10.4 \pm 0.6$ \\
\hline & $282 \pm 1$ & $3.8 \times 10^{12}$ & $2.4 \times 10^{11}$ & 0 & $4.7 \pm 0.4$ \\
\hline & $283 \pm 1$ & $24.7 \times 10^{12}$ & $10.1 \times 10^{11}$ & 0 & $30.5 \pm 1.8$ \\
\hline & $282 \pm 2$ & \multicolumn{4}{|c|}{ Average: $\mathrm{k}=(1.2 \pm 0.1) \times 10^{-18} \mathrm{~cm}^{3}$ molecule $\mathrm{s}^{-1} \mathrm{~s}^{-1}$} \\
\hline & $290 \pm 1$ & $15.4 \times 10^{12}$ & $6.2 \times 10^{11}$ & 0 & $24.2 \pm 0.8$ \\
\hline & $289 \pm 1$ & $17.4 \times 10^{12}$ & $11.8 \times 10^{11}$ & 0 & $26.5 \pm 1.2$ \\
\hline & $289 \pm 1$ & $11.2 \times 10^{12}$ & $5.1 \times 10^{11}$ & 0 & $17.5 \pm 0.6$ \\
\hline & $289 \pm 1$ & $14.1 \times 10^{12}$ & $5.9 \times 10^{11}$ & 0 & $22.2 \pm 0.8$ \\
\hline & $288 \pm 1$ & $20.0 \times 10^{12}$ & $7.1 \times 10^{11}$ & 0 & $30.7 \pm 1.5$ \\
\hline & $289 \pm 1$ & \multicolumn{4}{|c|}{ Average: $\mathrm{k}=(1.5 \pm 0.2) \times 10^{-18} \mathrm{~cm}^{3}$ molecule ${ }^{-1} \mathrm{~s}^{-1}$} \\
\hline
\end{tabular}


Table 3: Reactions of $\mathrm{O}_{3}$ with Methyl vinyl ketone (MVK): Initial experimental conditions and results from the kinetic studies

\begin{tabular}{|c|c|c|c|c|c|}
\hline & $\mathrm{T}(\mathrm{K})$ & $\begin{array}{c}{[\text { ozone }]_{0}} \\
\left(\text { molecule } \mathrm{cm}^{-3}\right)\end{array}$ & $\begin{array}{c}{[\mathrm{MVK}]_{0}} \\
\left(\text { molecule cm } \mathrm{cm}^{-3}\right)\end{array}$ & $\begin{array}{l}{[\text { cyclohexane] }} \\
\left(\text { molecule }^{-3}\right)\end{array}$ & $\begin{array}{c}k^{\prime}-k_{\text {loss }}^{\prime}( \pm 1 \delta) \\
\left(\times 10^{-5} \mathrm{~s}^{-1}\right)\end{array}$ \\
\hline \multirow{6}{*}{$\begin{array}{c}\mathrm{O}_{3} \text { in excess } \\
\text { with } \mathrm{OH} \\
\text { scavenger }\end{array}$} & $286 \pm 1$ & $2.9 \times 10^{12}$ & $2.3 \times 10^{11}$ & $3.9 \times 10^{13}$ & $1.1 \pm 0.1$ \\
\hline & $288 \pm 1$ & $5.1 \times 10^{12}$ & $4.7 \times 10^{11}$ & $4.1 \times 10^{13}$ & $2.1 \pm 0.1$ \\
\hline & $288 \pm 1$ & $6.9 \times 10^{12}$ & $5.5 \times 10^{11}$ & $5.9 \times 10^{13}$ & $2.8 \pm 0.2$ \\
\hline & $290 \pm 1$ & $3.8 \times 10^{12}$ & $2.8 \times 10^{11}$ & $3.9 \times 10^{13}$ & $1.5 \pm 0.1$ \\
\hline & $292 \pm 1$ & $5.4 \times 10^{12}$ & $4.9 \times 10^{11}$ & $5.8 \times 10^{13}$ & $2.3 \pm 0.2$ \\
\hline & $289 \pm 3$ & \multicolumn{4}{|c|}{ Average: $\mathrm{k}=(4.5 \pm 0.1) \times 10^{-18} \mathrm{~cm}^{3}$ molecule $\mathrm{e}^{-1} \mathrm{~s}^{-1}$} \\
\hline \multirow{5}{*}{$\begin{array}{c}\mathrm{O}_{3} \text { in excess } \\
\text { without } \mathrm{OH} \\
\text { scavenger }\end{array}$} & $286 \pm 1$ & $8.5 \times 10^{12}$ & $7.6 \times 10^{11}$ & 0 & $4.2 \pm 0.2$ \\
\hline & $287 \pm 1$ & $8.0 \times 10^{12}$ & $7.0 \times 10^{11}$ & 0 & $4.0 \pm 0.5$ \\
\hline & $289 \pm 1$ & $6.4 \times 10^{12}$ & $6.3 \times 10^{11}$ & 0 & $3.1 \pm 0.4$ \\
\hline & $289 \pm 1$ & $4.2 \times 10^{12}$ & $3.0 \times 10^{11}$ & 0 & $2.0 \pm 0.1$ \\
\hline & $287 \pm 2$ & \multicolumn{4}{|c|}{ Average: $\mathrm{k}=(5.1 \pm 0.1) \times 10^{-18} \mathrm{~cm}^{3}$ molecule $^{-1} \mathrm{~s}^{-1}$} \\
\hline
\end{tabular}


Table 4: The OH yields from the ozonolysis of isoprene, MACR and MVK: experimental conditions and results

\begin{tabular}{|c|c|c|c|c|}
\hline $\begin{array}{c}{[\mathrm{cHX}] /} \\
{[\text { organic }]_{0}}\end{array}$ & $\begin{array}{c}\text { [cyclohexanone]/ } \\
\Delta[\text { organic] }\end{array}$ & $\mathrm{Y}_{\mathrm{OH}}(\%)$ & Method & Reference \\
\hline \multicolumn{5}{|c|}{ Isoprene+O $\mathrm{O}_{3}$} \\
\hline 145 & $(12.49 \pm 0.21) \times 10^{-2}$ & $25.0 \pm 0.4$ & \multirow{8}{*}{$\begin{array}{c}\text { cHX as Scavenger } \\
\text { PTR-ToF-MS }\end{array}$} & \\
\hline 130 & $(13.07 \pm 0.24) \times 10^{-2}$ & $26.1 \pm 0.5$ & & \\
\hline 240 & $(14.02 \pm 0.16) \times 10^{-2}$ & $28.0 \pm 0.3$ & & \\
\hline 245 & $(13.60 \pm 0.29) \times 10^{-2}$ & $27.2 \pm 0.7$ & & \\
\hline 245 & $(11.12 \pm 0.24) \times 10^{-2}$ & $22.2 \pm 0.5$ & & \\
\hline 270 & $(11.99 \pm 0.20) \times 10^{-2}$ & $24.0 \pm 0.4$ & & \\
\hline 220 & $(12.91 \pm 0.16) \times 10^{-2}$ & $25.8 \pm 0.3$ & & \\
\hline 250 & $(12.53 \pm 0.21) \times 10^{-2}$ & $25.1 \pm 0.4$ & & \\
\hline 200 & $(11.64 \pm 0.65) \times 10^{-2}$ & $23.3 \pm 1.3$ & cHX as Scavenger, GC- & \\
\hline 230 & $(11.31 \pm 1.21) \times 10^{-2}$ & $22.6 \pm 2.5$ & MS & \\
\hline \multirow[t]{5}{*}{180} & $(10.85 \pm 0.48) \times 10^{-2}$ & $21.7 \pm 0.9$ & & \\
\hline & \multirow[t]{4}{*}{ Average } & $24.0 \pm 2.0 *$ & $\mathrm{cHX}$ as Scavenger & This work \\
\hline & & $26 \pm 2$ & $\begin{array}{l}\text { cHX as Scavenger, } \\
\text { TMB tracer, FAGE }\end{array}$ & 11 \\
\hline & & $28 \pm 5$ & LIF and FAGE & 2 \\
\hline & & 25 & Recommendation & IUPAC \\
\hline \multicolumn{5}{|c|}{$\mathrm{MACR}+\mathrm{O}_{3}$} \\
\hline 192 & $(8.56 \pm 0.66) \times 10^{-2}$ & $17.1 \pm 1.8$ & \multirow{5}{*}{$\begin{array}{l}\text { cHX as Scavenger } \\
\text { PTR-ToF-MS }\end{array}$} & \\
\hline 240 & $(7.99 \pm 0.66) \times 10^{-2}$ & $16.0 \pm 1.9$ & & \\
\hline 330 & $(5.01 \pm 0.37) \times 10^{-2}$ & $10.0 \pm 1.0$ & & \\
\hline 240 & $(7.84 \pm 0.58) \times 10^{-2}$ & $15.6 \pm 1.7$ & & \\
\hline \multirow[t]{3}{*}{270} & $(6.33 \pm 0.51) \times 10^{-2}$ & $12.7 \pm 1.4$ & & \\
\hline & \multirow[t]{2}{*}{ Average } & $14.3 \pm 3.5$ & $\mathrm{cHX}$ as Scavenger & This work \\
\hline & & $20^{+10}{ }_{-13}$ & $\begin{array}{l}\text { cHX as Scavenger GC- } \\
\text { MS/GC-FID/GC-FTIR }\end{array}$ & 15 \\
\hline \multicolumn{5}{|c|}{$\mathrm{MVK}+\mathrm{O}_{3}$} \\
\hline 82 & $(5.47 \pm 0.66) \times 10^{-2}$ & $11.0 \pm 1.9$ & \multirow{5}{*}{$\begin{array}{l}\text { cHX as Scavenger, } \\
\text { PTR-ToF-MS }\end{array}$} & \\
\hline 86 & $(9.39 \pm 1.08) \times 10^{-2}$ & $18.8 \pm 2.2$ & & \\
\hline 107 & $(3.8 \pm 0.70) \times 10^{-2}$ & $7.6 \pm 1.6$ & & \\
\hline 140 & $(9.82 \pm 1.30) \times 10^{-2}$ & $19.6 \pm 2.9$ & & \\
\hline \multirow[t]{4}{*}{119} & $(5.03 \pm 1.18) \times 10^{-2}$ & $10.1 \pm 1.1$ & & \\
\hline & \multirow[t]{3}{*}{ Average } & $13.4 \pm 4.1$ & $\mathrm{cHX}$ as Scavenger & This work \\
\hline & & $16 \pm 8$ & $\begin{array}{l}\text { cHX as Scavenger GC- } \\
\text { MS/GC-FID/GC-FTIR }\end{array}$ & 15 \\
\hline & & $16 \pm 5$ & tracers, GC-FID & 12 \\
\hline
\end{tabular}

Errors quoted are standard deviation (SD) obtained in the regression analysis combined with estimated overall uncertainties in the PTR-ToF-MS and GC-MS response factors for isoprene, MACR, MVK and cyclohexanone. * Average values determined by PTR-ToF-MS and GC-MS. 
Table 5: The product yields of the ozonolysis of isoprene, MACR and MVK under different experimental conditions.

\begin{tabular}{|c|c|c|c|c|c|c|c|c|c|c|}
\hline Exp. & [organic] & {$\left[\mathrm{O}_{3}\right]$} & $\mathrm{Y}_{\mathrm{MACR}}(\%)$ & $\mathrm{Y}_{\mathrm{MVK}}(\%)$ & $\mathrm{Y}_{\mathrm{CO}}(\%)$ & $\mathrm{Y}_{\mathrm{HCOOH}}(\%)$ & $\mathrm{Y}_{\mathrm{HCHO}}(\%)$ & YMGLYOX $_{\text {(\%) }}$ & $\mathrm{T}(\mathrm{K})$ & Reference \\
\hline \multicolumn{11}{|c|}{ Isoprene $+\mathrm{O}_{3}$} \\
\hline No Scavenger & $2.5-8.9$ & $0.3-0.9$ & $29 \pm 6$ & $10 \pm 1$ & $26 \pm 6$ & $3 \pm 1$ & $45 \pm 9$ & - & $283-286$ & This work* \\
\hline No Scavenger & $0.4-2.3$ & $3.3-25.3$ & $36 \pm 7$ & $13 \pm 3$ & $38 \pm 2$ & $4 \pm 1$ & $69 \pm 10$ & - & $281-288$ & \\
\hline $\mathrm{w} / \mathrm{cHX}$ & $0.4-1.5$ & $4.1-23.8$ & $32 \pm 5$ & $11 \pm 1$ & $54 \pm 4$ & $4 \pm 1$ & $90 \pm 2$ & - & 286-295 & \\
\hline $\mathrm{w} / \mathrm{cHX}$ & 2.4 & 14.4 & $42 \pm 6$ & $18 \pm 6$ & - & 5 & $81 \pm 6$ & - & 295 & 2 \\
\hline $\mathrm{w} / \mathrm{CO}$ & 400 & 24 & $33.4 \pm 4.2$ & $15.2 \pm 0.3$ & - & - & - & - & 295 & 22 \\
\hline No Scavenger & 127 & 55.2 & $34 \pm 1$ & $14 \pm 1$ & $26 \pm 1$ & $5 \pm 1$ & $68 \pm 3$ & - & $295 \pm 2$ & 21 \\
\hline No Scavenger & 120 & 55 & & & - & 4 & - & - & & 23 \\
\hline $\mathrm{w} / \mathrm{CO}$ & $504-576$ & $200-230$ & 30 & 20 & - & - & 55 & - & 298 & 20 \\
\hline No Scavenger & $504-576$ & $200-230$ & 28 & 21 & - & - & 54 & - & 298 & 20 \\
\hline $\mathrm{w} / \mathrm{cHX}$ & $45-48$ & 5 & $38.7 \pm 3$ & $15.9 \pm 1.3$ & - & - & - & - & $296 \pm 2$ & 19 \\
\hline No Scavenger & $45-48$ & 5 & $33.9 \pm 2.6$ & $19.1 \pm 1.5$ & & & & & $296 \pm 2$ & 19 \\
\hline w/methyl-cHX & $240-272$ & 5760 & 37 & 17 & - & - & - & - & $298 \pm 8$ & 18 \\
\hline No Scavenger & $312-408$ & 5760 & $67 \pm 9$ & $26 \pm 6$ & & & & & $298 \pm 8$ & 18 \\
\hline No Scavenger & 55 & 77 & $>33$ & $>13$ & - & - & 85 & - & & 17 \\
\hline \multirow[t]{2}{*}{ No Scavenger } & 22.3 & 16.9 & 41 & 18 & - & - & $90 \pm 5$ & - & 295 & 16 \\
\hline & & & $39-44$ & $16-17$ & - & - & 90 & - & & IUPAC \\
\hline \multicolumn{11}{|c|}{$\mathrm{MACR}+\mathrm{O}_{3}$} \\
\hline No Scavenger & $0.4-0.9$ & $7.1-24.9$ & & & $55 \pm 4$ & $3 \pm 1$ & $57 \pm 8$ & $59 \pm 9$ & $281-290$ & This work* \\
\hline $\mathrm{w} / \mathrm{cHX}$ & $0.3-0.8$ & $8.7-24.9$ & & & $59 \pm 4$ & & $66 \pm 4$ & - & $285-288$ & \\
\hline $\mathrm{w} / \mathrm{cHX}$ & 21 & $1.4-2.1$ & & & & & $12 \pm 3$ & $58 \pm 6$ & 293 & 24 \\
\hline \multicolumn{11}{|c|}{$\mathrm{MVK}+\mathrm{O}_{3}$} \\
\hline No Scavenger & $0.7-0.8$ & $6.4-8.5$ & & & $28 \pm 4$ & $4 \pm 1$ & $38 \pm 6$ & $71 \pm 6$ & $286-289$ & This work* \\
\hline $\mathrm{w} / \mathrm{cHX}$ & $0.5-0.8$ & $5.4-8.7$ & & & $30 \pm 8$ & - & $44 \pm 5$ & - & 282-292 & \\
\hline $\mathrm{w} / \mathrm{cHX}$ & 20 & 2.1 & & & - & - & 5 & $87 \pm 5$ & 293 & 24 \\
\hline
\end{tabular}

The units of [organic] and $\left[\mathrm{O}_{3}\right]$ in $\times 10^{12}$ molecule $\mathrm{cm}^{-3}$, MGLYOX=methylglyoxal. * Average values determined from different experiments. Errors quoted are 1 standard deviation (SD) of different experiments. 
Table 6. Initial experimental conditions and results of secondary organic aerosol (SOA) mass concentration $\left(\Delta \mathrm{M}_{0}\right)$ and $\mathrm{SOA}$ yield $\left(\mathrm{Y}_{\mathrm{SOA}}\right)^{\mathrm{a}}$.

\begin{tabular}{cccccccc}
\hline Experimental conditions & $\begin{array}{c}{[\mathrm{ISO}]_{0}} \\
(\mathrm{ppb})\end{array}$ & {$\left[\mathrm{O}_{3}\right]_{0}(\mathrm{ppb})$} & $\begin{array}{c}\mathrm{cHX} \\
(\mathrm{ppm})\end{array}$ & $\begin{array}{c}{[\mathrm{ISO}]_{\text {consumed }}} \\
(\mathrm{ppb})\end{array}$ & $\begin{array}{c}\Delta \mathrm{M}_{0}(\mathrm{max}) \\
\left(\mu \mathrm{gg} / \mathrm{m}^{3}\right)\end{array}$ & $\begin{array}{c}\mathrm{Y}_{\text {SOA }} \\
(\%)\end{array}$ & $\mathrm{T}(\mathrm{K})$ \\
\hline & 354.6 & 27.4 & - & $29.0 \pm 1.6$ & $2.9 \pm 0.15$ & $3.3 \pm 0.3$ & $283 \pm 1$ \\
ISO in excess w/o cHX & 158.2 & 33.7 & - & $23.5 \pm 2.5$ & $0.8 \pm 0.1$ & $1.1 \pm 0.1$ & $281 \pm 1$ \\
& 220.6 & 42.5 & - & $35.1 \pm 3.6$ & $6.4 \pm 0.5$ & $6.1 \pm 1.0$ & $281 \pm 1$ \\
& 75.1 & 849.0 & - & $64.7 \pm 0.9$ & $2.0 \pm 0.1$ & $1.0 \pm 0.05$ & $288 \pm 1$ \\
$\mathrm{O}_{3}$ in excess w/o cHX & 64.6 & 627.5 & - & $54.6 \pm 1.1$ & $1.9 \pm 0.2$ & $1.1 \pm 0.2$ & $285 \pm 1$ \\
& 45.0 & 504.1 & 6.6 & $22.6 \pm 2.8$ & $0.06 \pm 0.01$ & $0.09 \pm 0.02$ & $286 \pm 1$ \\
& 58.6 & 670.9 & 7.5 & $31.4 \pm 4.5$ & $0.25 \pm 0.01$ & $0.26 \pm 0.04$ & $295 \pm 1$ \\
$\mathrm{O}_{3}$ in excess w/ cHX & 90.1 & 965.4 & 16.9 & $78.3 \pm 1.8$ & $2.1 \pm 0.12$ & $0.89 \pm 0.09$ & $294 \pm 1$ \\
& 58.4 & 672.5 & 11.8 & $32.6 \pm 2.9$ & $0.52 \pm 0.05$ & $0.53 \pm 0.07$ & $291 \pm 1$ \\
\hline
\end{tabular}

${ }^{\mathrm{a}}$ Stated uncertainties were from scatter in particle volume measurements; ${ }^{\mathrm{b}}$ Assuming a density of $1.0 \mathrm{~g} / \mathrm{cm}^{3}$; ${ }^{\mathrm{c}}$ SOA yields were obtained from the maximum aerosol volume; 